\title{
Peter Sloterdijk, Skum og religion
}

\author{
En oversigt og indføring
}

\author{
HANS J. LUNDAGER JENSEN
}

ENGLISH ABSTRACT: Introduction to the work of Peter Sloterdijk, with special attention to his ideas on religion. The article first gives an overview of the main subjects of some of the most important books: Critique of Cynical Reason, the three volumes in the Spheres-trilogy: Bubbles, Globes, and Foams and In the World Interior of Capital. Subsequently, it explains the main topics in the work such as postenlightenment, immunity systems, anthropology, and theories of social life. Finally, it discusses the main issues in Sloterdijk's thoughts on religion, based on books such as Rage and Time, and God's Zeal.

DANSK RESUME: Religionsvidenskabelig orienteret indføring i Peter Sloterdijks værk, med særlig opmærksomhed på hans religionsteori. Artiklen giver forst et overblik over hovedværker: Kritik af den kyniske fornuft, trebindsværket om Sfærer: 'Bobler', 'Glober' og 'Skumdannelser' samt 'I den kapitalistiske verdens indre rum'. Derefter følger en redegørelse for de vigtigste emner $i$ varket: post-oplysning, immunsystemer, antropologi og teorier om menneskers liv sammen. Til sidst diskuteres Sloterdijks religionsteori som den er fremlagt $i$ bøgerne Vrede og tid og Guds iver. $^{1}$

KEYWORDS: Peter Sloterdijk; post-enlightenment; immune systems; anthropology; globalization; space; spheres; religion.

\section{Indledning}

Artiklen er tænkt som en generel og bredt anlagt indføring på dansk i Peter Sloterdijks tænkning og forfatterskab. Mit overordnede synspunkt er at der er brug for en

$1 \quad$ Indtil nu er kun den første af de nævnte værker oversat til dansk; de øvrige titelangivelser er derfor kun mine forslag til mulige oversættelser. De tyske titler fremgår af det følgende og af litteraturlisten. - Da jeg fortløbende vil henvise til et større antal af Sloterdijks arbejder, fraviger jeg her den normale henvisningsform i RvT med årstal til fordel for korttitler. Tak for kritiske bemærkninger til denne alt for lange artikel fra: Lars Albinus, Katrine Frøkjær Baunvig, Jørn Bjerre og Søren Hørning. 
sådan indføring på dansk, ikke mindst for læsere inden for feltet religionsvidenskab. Sloterdijks tænkning er umiddelbart relevant i to henseender: For det første formuleres her en forklaring på det nutidige der indbefatter en historisk rekonstruktion af hvorfor og hvordan nutidig (sekulær, post-religiøs) virkelighedsforståelse afløste tidligere, 'traditionelle' og religiøst funderede virkelighedsforståelser. Hans tænkning angår altså også hvordan en religionsvidenskab overhovedet blev mulig. For det andet er temaer som normalt regnes til religionsfænomenologien og religionshistorien, helt centrale i denne forklaring: Det gælder en fundamental forståelse af hvad 'rum' vil sige og hvorfor mennesker uvilkårlig skaber rum omkring sig (og ingen religion uden religiøst rum); og det gælder en forståelse af nutidig mentalitets rødder tilbage i det aksiale brud i midten af 1 . årt. f. Kr., hvor nødvendigheden i og legitimiteten af at bryde med traditioner, herunder religiøse traditioner, (formentlig) formuleres for første gang i menneskehedens historie. Artiklen er skrevet ud fra min personlige overbevisning om at religionsvidenskaben gør sig en tjeneste ved at sætte sig ind i Sloterdijks tænkning. Der er ganske vist flere forhindringer herfor. Sloterdijk er blevet stærkt kritiseret, og det forhold alene kan afholde fra at læse ham, eller tjene som praktisk påskud til at slippe for det. Jeg mener at det lønner sig, uanset ens holdning til kritikpunkterne i øvrigt.

Artiklen her er ikke en biografisk indføring. Givetvis er der en mængde punkter i det efterfølgende der er blevet sagt før, anderledes eller evt. bedre af andre. ${ }^{2}$ Men jeg tilstræber ikke her en systematisk redegørelse for inspirationskilder, forløbere og samtidige parallel-tænkninger. Jeg vil heller ikke gå i detaljer med de talrige polemikker, som Sloterdijk har deltaget i (om genteknologi, feminisme, skattepolitik, indvandring og nationalstat) og som har gjort ham til en kontroversiel person, som mange, vel navnlig på venstrefløjen, tager afstand fra (jf. oversigter i fx Wikipediaartikler på tysk og engelsk). Som det vil fremgå af artiklen her, finder jeg selv hans historiske analyser ganske overbevisende, hans samtidsdiagnoser dækkende og de implicitte fremtidsprognoser ofte præcise. At der også er formuleringer og enkeltræsonnementer, som næppe kan stå for en nærmere prøvelse, er her mindre afgørende.

Artiklen her er en opfølgning af og en slags supplement til min artikel om Peter Sloterdijks bog Du Musst dein Leben ändern i Religionsvidenskabeligt Tidsskrifts nr. 60 om religion og evolution (Lundager Jensen 2013). I det følgende vil jeg give en bredere anlagt beskrivelse. En blot tilnærmelsesvis fuldstændighed er ikke mulig. Sloterdijks forfatterskab er allerede nu enormt og ser ikke ud til at tage af foreløbig. ${ }^{3}$ I første omgang kan det tillige tage sig vildtvoksende ud, for der er tilsyneladende ingen ende på hvad der kan inddrages, fortælles om og forklares. Sloterdijk er dog

2 Fx savner jeg selv en ordentlig og grundig diskussion af Durkheims' samfunds- og religionsforståelse, som for mig at se på væsentlige punkter foregriber Sloterdijks forståelse for menneskelig gruppedannelse; jf. RvT 60, 90-95.

3 Litteratur om, inkl. diskussioner af og med, Sloterdijk er allerede omfattende. En god indføring kan fx ses i Schinkel \& Noordegraaf-Eelens 2011. En engelsksproget introduktion: Couture 2015. Mange af Sloterdijks bøger er i øvrigt oversat til engelsk, fransk, italiensk og spansk. 
grundlæggende filosof; hans baggrund her er særlig Nietzsche ${ }^{4}$ og Heidegger ${ }^{5}$, og han refererer løbende til navnlig nyere fransk filosofi og samfundstænkning (bl.a. Sartre, Foucault, Derrida, Deleuze, Latour), mens der omvendt er en polemisk front i forhold til Frankfurterskolen, selv om denne skole også er en vigtig bagrund og der ofte er positive referencer til en af dens grundlæggere, Theodor W. Adorno. ${ }^{6}$ Men kultur- og samfundsteori og ide- og mentalitetshistorie optager en stor plads i hans forfatterskab, og det er denne side der skal fremhæves i det følgende. For filosofien holdes til stadighed sammen med idehistorie i bredere forstand, inklusive æstetik (musik, billedkunst, design, arkitektur), ${ }^{7}$ teknologi og, ikke mindst, religion.

Selv dedikerede læsere ${ }^{8}$ vil nok have travlt med at følge med strømmen af Sloterdijks ofte omfangsrige publikationer. ${ }^{9}$ Men dels udvider læsningen læserens viden ganske betragteligt, dels er der også nogle hovedlinjer og generelle tendenser igennem hele værket som giver det konsistens og genkendelighed, og som gør at hvert enkelt værk kan være et sted at træde indenfor. For den mere øvede læser kan det så være en fornøjelse at møde de samme pointer formuleret på nye måder; den mindre øvede kan måske risikere at føle sig rundtosset af en mangfoldighed som kan forekomme mere uoverskuelig end den faktisk er. Et forhold der for nogle læsere kan være en hindring og for andre en tilskyndelse, er Sloterdijks litterære stil. ${ }^{10}$ Mange af hans sætninger og passager er formuleret så prægnant at hans tekster næsten virker som samlinger af potentielle, fremtidige citater der kan efterlade læseren i en fornemmelse af udmattet overstimulering. Ofte kan man stødes over brutale kategoriseringer eller over en gennemgående ironiserende tone. En mere saglig vanskelighed er de ofte egensindige ordkonstruktioner. Sloterdijks tænkning består helt gennemgående $i$ at gen- og om-tænke velkendte temaer (individ, samfund, kultur, religion, oplysning, modernitet ...). En af de største forhindringer for tænkningen er netop eksisterende ord, begreber og formuleringer; i kraft af deres blotte eksistens og bekendthedsgrad risikerer de at tilsløre reel uvidenhed eller fundamental usik-

4 Fx forelæsningen Über die verbesserung der guten Nachricht. Nietzsches fünftes "Evangelium" (2001).

5 Fx artikelsamlingen Nicht gerettet. Versuche nach Heidegger (2001). Couture 2015 gør meget mere ud af Sloterdijks afsæt i Heidegger, end jeg gør i artiklen her.

6 Jürgen Habermas og Axel Honneth, begge fremtrædende Frankfurter-filosoffer, hører til blandt de mest prominente blandt Sloterdijks mange kritikere.

7 Estetik fylder meget i Sphären I-III (jf. nedenfor); men jf. artikelsamlingen Der ästhetische Imperativ (2014).

8 Der nok typisk vil være dem som trilogien Sphären navnlig er tiltænkt: 'de som hver på deres egne felter bedriver grundlagsrefleksion, såsom arkitekter, klimatologer, sociologer, makrohistorikere, antropologer, læger, lærere og teologer': Ausgewählte Übertreibungen, 178.

9 Sloterdijks hidtil nyeste bog, Das Schelling-Projekt: Ein Bericht (2016), er en e-mail-udvekslingsroman om en mislykket forskningsrådsansøgning om kvindelig seksualitet som effekt af biokulturel evolution: dels det mysterium at det i menneskearten er hunner, ikke hanner, der udstyres overdådigt, dels det mysterium som er den kvindelige orgasme (jf. en artikel i New York Times' Science-del: Zimmer, 2016). Her væves den tyske romantisk-idealistiske filosof Schellings præevolutionære naturfilosofi sammen med temaer som fostertilstand og moderskød fra Sphären I, evolution som 'vertikal stræben' (også jf. nedenfor), Marcel Mauss' gaveteori, teologi, Islam og andet.

10 Jf. Lilian Munk Røsing anmeldelse af Sloterdijks Was Geschah i Politiken 2016-06-20: “Tysk filosof giver løsningen på verdens problemer". 
kerhed. I dilemmaet imellem velkendte ord med redefineret indhold og nye ord for nyt indhold foretrækker Sloterdijk den sidstnævnte mulighed. ${ }^{11}$ Det kan gøre læsningen besværlig; til gengæld bliver forståelsen mere præcis. I øvrigt rummer de talrige interviews og samtaler som Sloterdijk har medvirket i, ofte lettilgængelige sammenfatninger og spidsformuleringer. ${ }^{12}$ Alle disse vanskeligheder har ikke forhindret Sloterdijk i at blive læst; jeg mener af gode grunde.

\section{Forfatterskabet i store træk}

If. Sloterdijks egen website ${ }^{13}$ omfatter hans bibliografi indtil videre (10. nov. 2016) knap 40 selvstændige publikationer, fra 1976 til i dag. Nogle af disse er kortere tekster, typisk forelæsninger. Nogle er af normal, overkommelig længde: monografier, samlebind med artikler, interviews og lign. Men der er også tre særlig omfangsrige værker, som jeg her vil betragte som hovedværker og som kan bruges som markører for de vigtigste temaer i forfatterskabet som helhed. Imidlertid er det tredje af disse, Du Musst dein Leben ändern fra 2009, som sagt allerede blevet udførligt kommenteret her i Religionsvidenskabeligt Tidsskrift. Jeg vil derfor her nøjes med at henvise til dette værk i sammenhæng med oversigten over hvad Sloterdijk har kaldt sit religionsteoretiske forfatterskab (også selv om han har forbehold over for selve kategorien religion, som det vil fremgå nedenfor).

Det første højdepunkt er bogen Kritik der zynischen Vernunft fra 1983, der gjorde Sloterdijk berømt i brede akademiske kredse i Tyskland og internationalt; udvalgte dele af den er oversat til dansk. ${ }^{14}$ Her var endelig en tysk tænkning der var i kontinuitet med de samtidige franske, 'postmoderne' strømninger og med distance til grundlæggende selvfølgeligheder i den hidtil dominerende europæiske oplysningstænkning (i Tyskland mest kendt som Frankfurterskolen og dens 'kritiske teori'). Kritisk tænkning var kommet i krise ved etableringen af velfærds- og forbrugssamfundet. Efter de store ideologier - den borgerlige oplysning fra 1700-tallet og dens videreførelser (eller perverteringer) som kapitalistisk liberalisme og som venstre- og højrefløjs-totalitarismer - var der kommet en udbredt rådvildhed eller ligegyldighed over for oplysningens idealer og en skepsis over for relevansen af traditionel 'kritisk' tænkning. Den herskede stemning - en uentusiastisk accept af det socialtliberale samfund og dets forbrugsgoder - så Sloterdijk som en slags 'kynisme', en

11 Den modsatte holdning finder man hos den franske antropolog Philippe Descola $(2005,176)$, som ikke bryder sig om neologismer, og som derfor bevarer velkendte termer som 'animisme' og 'totemisme', men omdefinerer dem, dvs. fylder dem med nyt indhold. Det giver det modsatte problem: at læseren for let tror at forstå. Tilsvarende hos Bruno Latour (2005, 1f., redefinition af 'sociologi').

12 Et større udvalg af interviews er samlet i: Ausgewählte Übertreibungen; jf. samtalebøger: Die Sonne und der Tod (med Hans-Jürgen Heinrichs); Gespräche über Gott, Geist und Geld (med Thomas Macho). - Som et indledende skridt ind i det Sloterdijkske univers kan i øvrigt anbefales de knap så omfangsrige monografier: Im Weltinnenraum des Kapitals, Zorn und Zeit, Die schrecklichen Kinder der Neuzeit.

13 http://petersloterdijk.net/

14 Sloterdijk, Kritik af den kyniske fornuft, Hans Reitzel 1989. 
anti-idealistisk indretning på en epokes vilkår, som nok lå langt fra tidligere generationers drømmemål, og hvis uretfærdigheder og mangler var erkendt, men som dog var til at holde ud at leve i - ikke mindst i sammenligning med de totalitaristiske ideologiers menneskeforagtende højkynisme. Over for den moderne kynisme (der på tysk kan skrives som Zynismus) stillede Sloterdijk et alternativ: den antikke græske kynisme (tysk: Kynismus) i traditionen tilbage til Diogenes fra Sinope - en antifilosof der parodierede Platons og andre samtidige filosoffers abstraktioner med sin egen bizarre, 'hundeagtige' adfærd (deraf 'kyniker' = som en kýnos, 'hund'). 'Kritik' i traditionel forstand som 'afsløring' af uretfærdigheder, illusioner og fortrængninger var blevet irrelevant. 'Man' vidste sådan set godt at meget i verden var ringere, end det ideelt set burde være. Men der var ikke så meget at gøre ved det, for der var ikke længere håndfaste og troværdige alternativer; protester kunne kun være punktuelle og lokale, ikke globale og altomfattende. Alternativer til den 'kyniske' accept kunne derfor kun være punktvise og konkrete 'kyniske' og 'frække' parodier som dem Diogenes praktiserede.

Der var mange lighedspunkter her til en mere klassisk eksistentialisme (Sartre og andre) efter Anden Verdenskrig. Men også denne stod svagt ved sin individualitetspatos, hvor hver enkelt skulle skabe 'mening' i en formodet meningsløs verden ved at etablere identitet ikke igennem overtagelse af traditionelle roller og former, men igennem egne valg og egne handlinger som ikke kunne legitimeres med henvisninger til nogle andre og 'større' instanser (såsom Gud eller tradition). For if. Sloterdijk var det ikke indlysende at dementiet af de store utopier - der jo netop ville have været 'meningsgivende' projekter - i sig selv var argument for at menneskene så var dømt til at leve i en meningsløs verden. Ved siden af 'kynisme' i stil med Diogenes anbefalede Sloterdijk også en 'asiatisk' accept af det givne, en slags 'visdom' der uden forbitrelse eller ressentiment på egne eller andres vegne accepterede at verden er større end menneskene, og at overilede tiltag til at omkonstruere verden har medført uforudsete katastrofer - hvis da ikke, som i det 20. års. ekstremistiske ideologier, katastroferne tilmed var kynisk forudsete og planlagte. ${ }^{15}$

En mindre bog fra 1993 er Weltfremdheit, som fortsætter kyniker-temaet med at undersøge 'verdensflugt' i traditionelt religiøse former (som eneboer- og klosterliv, som gnosticisme og mystik) og i nutidige (fx som narkomani). Her anslås temaer som udfoldes dels i Du musst dein Leben ändern, dels i Sphären I, første del af det næste højdepunkt i forfatterskabet. Det kolossale værk i tre store bind med den samlede titel Sphären er en slags bud på en menneskehedens kulturhistorie fra fosteret i livmoderen til astronauter i rumstationer. Første bind, Blasen (altså 'blærer, bobler'), kom i 1998, det andet bind, Globen ('globusser, kugler') i 1999, og det tredje og sidste, Schäume ('skum, skumdannelser') i 2004. Grundideen med værket som helhed var at tænke menneskelig væren og den menneskelige historie (med eksempler overvejende fra den vestlige historie) i rumlige kategorier, ${ }^{16}$ altså som en historie over menneskelige rumdannelser, rumfornemmelser og rumopfattelser.

15 Kritik der zynischen Vernunft, 691f. 939f.

16 Sphären I, 46: De tre bøger 'sigter på at vise at (det eksistentielle) grundvilkår for mennesker er at eksistere i sfærer. Dette grundvilkår har så fra begyndelsen af været antastet af en ikke-indre- 
Rumdannelse er en antropologisk konstans - mennesker kan slet ikke lade være med at danne rum omkring sig - og menneskehed og rumformer har udviklet sig sammen og gensidigt. ${ }^{17}$ Dette udgangspunkt kan ses som Sloterdijks originale version af det mere almene fænomen 'den spatiale vending'. ${ }^{18}$ Som en opfølger og korrektur af Heideggers berømte værk Sein und Zeit ('væren og tid'; 192719) og eksistentialismens generelle overvurdering af tidslighed er værket en slags 'Sein und Raum' ('væren og rum'). ${ }^{20}$ Menneskets virkelighed er i højere grad rum: Rum kommer logisk, psykologisk og eksistentielt før tid. Mennesker er, og kommer til sig selv, i et rum (fra moderlivet til den primære gruppe, typisk den nære familie og en lokal gruppe), længe før de får nogen anelse om at de er i en tid og selv har tidslighed (dvs. et tidsrum at udfylde forud for den uundgåelige død). De bliver til i et rum eller en sfære - livmoderens beskyttende og veltempererede boble - og de fødes ind i rum, som de senere selv skal udfylde, opretholde eller forandre - typisk ved at gestalte og udvide det. Det menneskelige rum er materielt (og dermed er sfæreprojektet blevet relevant også for fx arkitekter og byplanlæggere ${ }^{21}$ ) og, navnligt, ikke-materielt: Det menneskelige rum er et 'resonansfællesskab'22, der består af kommunikation med andre mennesker, begyndende med fosterets fornemmelse af moderens krop og den allernærmeste omverden og erfaringen af den 'velkomstkomite' der normalt vil stå klar, når fosteret ledes ud i luften og lyset og bliver til en nyfødt. ${ }^{23}$

Fosteret er til, men kan ikke være bevidst om at det er til, fordi det er en del af noget større hvis omfang det ikke kan have nogen forestilling om, og som derfor ikke kan være en 'genstand', et 'objekt' for dets erkendelse. Først i og med fødslen etableres mulighedsbetingelsen for dannelse af et erkendende og handlende subjekt der står på afstand af og over for noget andet, 'objekter'. For den endnu ufødte er livmoderen et 'nobjekt'. ${ }^{24}$ Det nødvendigvis tågede og ubestemte erindringsspor har til gengæld været drivkraft for længselsfulde drømme. Sådan vil Sloterdijk forstå neolitiske kulturers forestillinger om en livgivende jord-moder, begravelsesskikke hvor lig behandles som fostre, mystikkens mål som et mystiker-subjektets erfaring

verden (nicht-Innenwelt), som det stadig må hævde og beskytte sig imod. Sfærer er derfor også altid auto-immunologiske dannelser'.

17 Sloterdijk, "Talking to Myself about the Poetics of Space" (2009): "humans are themselves an effect of the space they create (...) Humans are pets that have domesticated themselves in the incubators of early cultures.".

18 En introduktion kan ses i Jo Guldi, “What is the Spatial Turn?" på http://spatial.scholarslab.org/spatial-turn/ (set 2016-08-22). Jf. Knott 2008.

19 Dansk oversættelse ved Christian Rud Skovgaard: Væren og tid, Klim 2007.

20 Sphären II, 59. En nærmere redegørelse for den potentielle, men uudnyttede rum-analyse hos Heidegger: Sphären I, 336-45. En nærmere diskussion af Sloterdijks Heidegger-analyse her og en god generel redegørelse for Sphären-projektet: Morin 2009.

21 Navnlig Sphären III: Schäume har udførlige overvejelser over nutidig og fremtidig rumgestaltning.

22 Ausgewählte Übertreibungen 187.

23 Ausgewählte Übertreibungen 448; med 'varme hænder', kunne man sige på dansk. - Den kristne dåb er en tredje, hyperkulturel udvidelse af den velkomst til verden som den nyfødte mødes med på først biologisk, så lokalt-kulturelt niveau (Sphären I, 628).

24 Begrebet 'nobjekt' har Sloterdijk lånt fra den tyske filosof Thomas Macho (Sphären I, 288). 
af at være udslukket eller udtømt, i og med at have nået dette 'nobjekt' - og paradisforestillinger af alle slags. ${ }^{25}$

Denne svangerskabs-foster-fødsels-analyse eller - beskrivelse er ment som et alternativ til en populær forestilling, ikke mindst i kraft af eksistentialismen: At mennesket skulle være essentielt alene i verden, og at det vigtigste at sige om det skulle være at det, som Heidegger ville sige, står uhjælpeligt alene over for sin død (hvorfra kultur i princippet kan genereres, fx, og ikke mindst, religion - som afværgelse eller bemestring af døden). ${ }^{26}$ Men if. Sloterdijk er mennesket netop ikke alene. Det er fundamentalt set altid sammen med andre, også selv når et menneske faktisk er alene: De andres stemmer og tanker fylder op i bevidstheden. Menneskers første erfaringer er fællesskab, og det er fra forsterstadiet af indrettet på fællesskab. ${ }^{27}$ Forud for den nyfødtes nærhed til moderen går fosterets samvær med moderkagen, placenta, der som en anden tvilling eller ledsager fødes sammen med barnet. Før moderniteten blev placenta ikke betragtet og behandlet som affald, men som en slags dobbeltgænger med vigtige egenskaber. Sloterdijk foreslår at forstå alle udbredte forestillinger om individers usynlige livsledsagere og beskyttere, om genius, skytsengel, ekstern sjæl og livstræ etc. som udtryk for denne allerførste erfaring om at have en tvilling hos sig. Selv om de faktiske forestillinger virker fantasmatiske i nutiden, var de i grunden mindre irrationelle end det typisk nutidige syn på mennesket som grundlæggende sig selv, enlig og isoleret. ${ }^{28}$ Selve begrebet 'individ' (altså noget 'udeleligt, latin in-dividuus), er altså problematisk: På den ene side er alle mennesker delte ('divider'!), fordi forskelligrettede stemmer høres, og ønsker og forestillinger i flere og modstridende retninger huses i samme krop. På den anden side rækker alle mennesker ud imod andre, forbinder sig med dem på godt og ondt, i interesse, begær, kærlighed, eller i misundelse eller had.

Allerede den varme som menneskefosteret erfarer, først i moderen, dernæst i den primære spædbarnsplejegruppe, gør mennesket til et 'forkælelsesvæsen'. Det vil stræbe efter at gendanne og udvide den oprindelige varme i både ligefrem og i metaforisk forstand. 'Samfund' (Sloterdijk er skeptisk over for selve begrebet, jf. nedenfor) er fra begyndelsen varmestuer eller drivhuse. Mennesker samles omkring lejrbål eller træder ind i rum med behagelig temperatur, og de erfarer 'varme' fra hinanden i deres venskaber og kulturelle fællesskaber. Ganske vist er den infantile varmeerfaring ikke tilstrækkelig som generator for menneskelig evolution, teknisk og kulturel, for den varme livmoder eller ægget i den lune rede kender alle fugle og pattedyr. En anden afgørende faktor kan antages at have været 'savanneerfaringen': Oprejst gang på jorden betyder også at udvide ens horisont i bogstavelig forstand ved at kunne se længere væk og dermed forud og i god tid registrere stressfakto-

25 Sphären I, 275-95; Das Schelling-Projekt, 234.

26 Jf. fx Sloterdijks kritik af Alain Badiou som eks. på den moderne-individualistiske antagelse at mennesker grundlæggende er alene og ensomme før de møder andre (Sphären I, 556).

27 Sphären I, 85; jf. Ausgewählte Übertreibungen, 448.

28 Sphären I, 347-465. 
rer. ${ }^{29}$ Det menneskelige rum er både varmestuer og stressfællesskaber med den funktion at beskytte - immunisere - imod farer og risici. Alle levende væsener er immunsystemer, systemer der frembringer sin egen beskyttelse imod udefrakommende farer. Det særlig menneskelige er at udvide med sociale og kulturelle hyperimmunsystemer i form af stammer, byer, nationer, kulturer, religioner.

Vejen fra foster til voksent menneske går selvfølgelig over nogle faser. Den første, placenta-inspirerede, 'tvilling' (eller 'intimgud', 'genius', etc.) erstattes med, eller tager skikkelse som, mere konkrete partnere, fra moderens bryst over personerne i det spæde barns omverden til den mangfoldighed af væsener der befolker den voksnes verden. Disse væsener - der alle bliver 'partnere', for så vidt som mennesket forholder sig til dem og altså danner sfærer med dem - omfatter både konkrete mennesker og mennesker der ikke er fysisk til stede (de er fx på rejse, eller de er døde) og imaginære væsener ( $f x$ engle, guder), og selv ting og genstande. I den amerikanske popkunstners Andy Warhols udsagn om at han havde giftet sig med sin båndoptager, ${ }^{30}$ kan man se det elektroniske apparat som en nutidig pladsholder for den første, intime 'Anden'. ${ }^{31}$ Nutidig ekstrem-individualisme og erklærede single-eksistenser vil ved nærmere eftersyn vise sig at dække over nære venskaber og quasi-erotiske kærlighedsforhold til TV-apparater og smartphones; en kulturelevolutionært lidt ældre udgave ville så være den bibliofiles forhold til sin bogsamling. Tilsyneladende individualisme vil i så fald ikke dementere påstanden om at mennesker grundlæggende er og til alle tider har været indrettet på partnere, på andre. Sphären I, der drejer sig om 'mikrosfærer', formulerer dermed en teori om 'stærke forbindelser' imellem mennesker som grundlæggende for hele Sphärentrilogien. ${ }^{32}$

Mens første bind af Sphären både er en slags alternativ psykoanalytisk teori ${ }^{33} \mathrm{og}$ en form for alternativ, ikke-patetisk eksistentialisme, er de to følgende bind nærmest kulturhistoriske udfoldninger af menneskehedens drift imod rumgestaltninger. Bind 2, om glober eller kugler, går fra mikro- til makro-sfærer og rekonstruerer den europæiske forestilling om kuglen som den ideale form, fra græsk-romersk tænkning $^{34}$ og op til moderniteten. Forestillingen om at alting kunne forstås inden for en globe, kugle, var fælles for både geometri, kosmologi og metafysik (og politik, jf. fx rigsæbler). Den emblematiske repræsentant var globussen, der vel at mærke oprin-

29 Ausgewählte Übertreibungen, 150f. - Temaet stress optræder hyppigt hos Sloterdijk; inspirationen er fra den tyske tænker Heiner Mühlmann; jf. fx Stress und Freiheit,12.

30 Jf. Sphären I, 469.

31 'Den Anden': dette at mennesker normalt står (eller oplever sig som stående) over for noget anderledes og udvendigt i forhold til dem selv: et begreb kendt fra bl.a. filosofi (fx Hegel) og psykoanalyse (navnlig Jacques Lacan); ens mor, ens far og ens sprog og kultur er sådanne 'Andre'.

32 Sphären I, 629.

33 Sloterdijk vil hermed skyde det afgørende punkt i subjekt-dannelsen tilbage fra Freuds Ødipuskompleks og Lacans spejlstadie (Sphären I, 543-48) til fosterets gradvise reaktion på omverdenen, primært moderens krop.

34 At Sloterdijk ansætter tidspunktet for forståelse af kuglen til den græske filosofi, passer godt med at den ikke var en idealform i GT (og formentlig slet ikke nævnes); her var det kvadrater eller kuber der var ideale former; jf. Lundager Jensen, 2016 om 'analogistisk' ontologi i GT; kugletænkning er formentlig 'analogismens' kulmination og afslutning. 
deligt og indtil engang i 1500-tallet hyppigere var en himmel- end en jordglobus. Idealet var her at forstå verden som en sammenhængende enhed: smuk, rund og rationel. Kuglen er en passende metafysisk grundfigur, for klassisk filosofisk metafysik implicerede at virkeligheden var sammenhængende, iagttagelig og forståelig. Tankegangen er godt kendt i middelalderlige indlejrende kuglesystemer som fx i Dantes lagdelte kosmologi med helvede i midten og purgatoriet som en forbindelsestrappe til de himmelske sfærer der hvælvede sig uden om jorden. Og denne tænkning var allerede en slags 'globalisering' (jf. nedenfor).

Men nutidig tænkning (og rumgestaltning) er post-metafysisk - det er udgangspunktet for det tredje bind, Shäume ('skum', i flertal: 'skumdannelser'). Virkeligheden er blevet så kompleks at ingen kan begribe den i tanken; det er derfor ikke længere overbevisende at den skulle kunne afbilledes som en kugle. Mens den metafysiske filosofi og dens fortsættelse i kristen middelalderteologi gik ud fra at virkeligheden var sammenhængende og rationel (og altså kugleformet), var det den europæiske oplysnings intention at gøre verden sammenhængende og rationel. Men oplysningsprincipper omsat til politisk handling har trukket katastrofer med sig, fra den franske revolutions guillotine til nutidens aktuelle rædsler. Flertallet af vestlige mennesker tror ikke på at verden er en kugle, eller at den bør eller kan gøres til en kugle.

Hvor kuglen var, er skummet kommet. Skum-billedet forener det fælles og det isolerende, at mennesker lever sammen og dog også har hvert deres liv, i hver deres boble. Skum medierer imellem kugleforestillingens overdrevne fællesskab og en plat og lige så urealistisk individualisme. Som sagt indgår alle mennesker i fællesskaber (om de vil det eller ej - selv søjlehelgener) - og mennesker er tydeligvis biologisk indrettet dertil; men de er normalt også mere eller mindre adskilte fra hinanden. Et indlysende nutidigt eksempel er lejligheder i en etageejendom, hvor mennesker bor sammen og dog hver for sig, ofte uden at have stor trang til at kende hinanden.

Derfor kan den menneskelige virkeligheds historie også fortælles som en evolution fra lejrbålets metaforiske drivhus til realiseringen af krystalpaladser ${ }^{35}$ og drivhuse i form af $\mathrm{fx}$ indkøbscentre og lufthavne. Nutiden bør forstås som resultatet af en evolution hvor menneskearten har søgt, og delvis opnået, magt over ikke kun ild, jord og vand, men senest også luft. ${ }^{36}$ Som i de fleste evolutionshistorier er ambivalensen ikke til at misforstå. Opvarmede og afkølede, overdækkede rum, hvor de fleste mennesker enten opholder sig, eller ønsker at opholde sig, det meste af deres tid, er realiseret i samme periode som menneskeartens forurening af luften udenom har nået et punkt hvor det bliver indlysende for de fleste at noget må gøres. Menneskearten er dermed, om den vil det eller ej, blevet atmosfærens herrer.

Evolution er altså ikke en blot bevægelse 'fremad', men i samme grad 'udad' og 'opad'. I det helt overordnede perspektiv går tendensen fra det mindre til det større,

35 Historiens første drivhus i stort format var det berømte 'krystalpalads', en udstillingsbygning med glasvægge til verdensudstillingen i London 1851.

36 En urbegivenhed i erkendelsen af at mennesker lever i og af luft og atmosfære, er brugen af giftgas under Første Verdenskrig (Sphären III, 90). 
fra det enkle til det komplekse, fra det overskuelige, forståelige og styrbare til det uoverskuelige, uforståelige og ustyrlige. Ofte vil denne tendens modvirkes af talrige modsatrettede bevægelser. Skummet er dynamisk: Det kan udvide sig; men det kan også klaske sammen. Det kan vokse ved at der dannes mange bobler, eller flere bobler kan briste, end nye dannes. Skum er altså en metafor eller en tankefigur som kan sammenlignes med andre fundamental-billeder: rhizom (rodsystem) hos Deleuze og Guattari og netværk hos Latour. Det fælles ved disse forskellige og konkurrerende tanke-figurer er at de er anti-kugler: De er alle centrumløse, mangfoldige, komplekse og potentielt uoverskuelige. For Sloterdijk at se har skum den fordel frem for netværk at den tænker virkeligheden som en flerhed af rum der alle grænser op til hinanden og den fordel frem for rhizom at den i sig rummer muligheden for vertikal udvidelse. ${ }^{37}$ Virkeligheden er ikke blevet mindre i den post-metafysiske virkelighed. Tværtimod vokser 'rummet' både i bredde og i højde og omfatter nu også den nærmeste del af verdensrummet i form af menneskeskabte sonder, satellitter og ekstra-terrestriske koloniseringsplaner, med rumstationen som det hidtil mest tydelige eksempel på et menneskeskabt immunsystem.

Med rummet vokser også menneskenes muligheder for at frigøre sig fra jorden. I det 20. årh. fik menneskene - de af dem der levede og lever i nutidens både reelle og metaforiske drivhuse - hidtil ukendte muligheder for at blive lettere, igen: både i håndgribelig og i overført betydning. De teknisk skabte muligheder for at bevæge sig i luften, fra flyvemaskiner til rumskibe, er eksempler på den materielle side af en generel vægtløshed, 'ubestemthed og lethed, altså den stemning, der gerne bliver forbundet med begrebet om det 'post-moderne' i de vestlige-kapitalistiske befolkninger: en upatetisk ignorering af tidligere generationers store og 'tunge' temaer (fra religion til revolution), en fornemmelse af at man kan leve et relativt meningsfuldt liv, selv om det forbliver noget uklart hvad det hele i sidste instans skal være godt for.

Fornemmelsen af at svæve kan spores helt til aktuel erkendelsesteori. Mens traditionel filosofi og videnskab gjorde sig store anstrengelser for at 'fundere', at give de bedst mulige begrundelser eller betingelser for hvad der er sandt og rigtigt, gør filosofi og videnskab sig nu omvendte anstrengelser for at demonstrere at der ikke er nogen sidste instans, ikke er nogen altid gyldig og urokkelig sandhed eller evidens: 'De mest seriøse vindeskabsmænd forsikrer os om at vore 'sidste grunde' i sidste instans svæver i luften' ${ }^{38}$ Sloterdijk registrerer denne lethed som et vilkår i en posteller senmoderne tilværelse (men altså uden selv i sit tungt-vejende forfatterskab at tage let på sagen). Sphären II munder ud i en opfordring til at gentænke vilkårene for hvordan store grupper af mennesker kan etablere eller opretholde beboelige rum: 'Den egentlige psykosociale udfordring i den globale tidsalder (...) består i ikke at nøjes med at forstå svækkelsen af de traditionelle etniske container-immuniteter

37 Sloterdijk, Ausgewählte Übertreibungen, 177. 253. Netværk og skum er konvergente forsøg på en metafor eller et billede for den aktuelle virkelighedsoplevelse (Latour, 2009). - Sloterdijks generelle kritik af Deleuze \& Guattaris 'laterale', men anti-vertikale, rhizom-tænkning: Sphären III, 301f. 663; Die Sonne und der Tod, 249f.; Die schrecklichen Kinder 470-81.

38 Die Sonne und der Tod, 2006, 244. 
som formtab og dekadence (...). Hvad det drejer sig om for de postmoderne er succesfulde designs af leveduelige immunforhold' ${ }^{39}$ Sloterdijk vil fastholde at de moderne nationalstater på mange måder var beundringsværdige konstrukter, som 'for flertallet af sine beboere etablerede en slags hjemlighed, altså en samtidig imaginær og virkelig immunstruktur, der kunne erfares som en konvergens af Sted og Selv, dvs. som regional identitet $(\ldots)^{\prime} \cdot{ }^{40} \mathrm{I}$ en individualiseret virkelighed etablerer enkeltpersoner deres egne immunsystemer. Nutidens kultur af selvcentrerede individualister er historisk usædvanlig - om det er udtryk for en særlig eksistentiel fitness eller for eksistentiel dekadence, er endnu uafgørligt. ${ }^{41}$

Globaliseringen er også tema for bogen Im Weltinnenraum des Kapitals (2006), der viderefører tankegangen fra Sphären II. Forestillingen om 'globalisering' som en karakteristik af verdens aktuelle tilstand er upræcis, fordi den fejlagtigt giver indtryk af at rundheden og sammenhængen er ved at etablere sig eller er noget som har etableret sig for nylig. Men forestillingen om jordens rundhed blev som sagt allerede udtænkt i den tidlige, vestlige filosofi. Termen 'globalisering' kan på den anden side forlede til at se nutidens form som universel, mens den reelt kun gælder for dem der er indenfor i den økonomiske comfort-zones drivhus. ${ }^{42}$ Det relevante er erkendelsen af kompleksiteten af subkulturer og individualiteter og de uoverskuelige netværk. Relevansen af tankefiguren 'rundhed' ${ }^{43}$ er dermed blevet dementeret; tænkning på højde med nutiden tænker det ikke-runde, det uoverskuelige, det der ikke hænger glat sammen med alt muligt andet. ${ }^{4}$

Globaliseringen har haft en række faser, og den fase hvor det blev muligt for mennesker at bevæge sig rundt på jordens overflade, blev realiseret for århundreder siden. Selv om jorden teoretisk var forstået som en kugle allerede af den græske filosofi, blev den først rigtigt erfaret som sådan fra og med anden halvdel af 1400tallet, dvs. 'opdagelsesrejserne', jf. den første verdensomsejling 1519-1522. Rejserne, med formål der omfattede opdagelse, plyndring, handel, erobring, mission, udgik fra Vesteuropa og var i høj grad maritime - og beherskelse af havet kom herefter til at definere militær og politisk magt, kulminerende med det landbundne NaziTysklands nederlag. ${ }^{45}$

Succeserne indebar en mentalitetsforandring i den europæiske kultur. Bevidstheden blev fremtidsrettet frem for fortidsrettet. Den dominerende forestilling

39 Sphären II, 1003.

40 Sphären II, 997.

41 Sphären II, 1005. Formentlig mener Sloterdijk nærmest det sidste. Hans kritik af den 20. årh.s venstrefløjstænkning har fået hans kritikere til at rubricere ham som 'konservativ'. If. Sloterdik selv er hans position snarest 'venstre-konservativ' (jf. interviewet: “Der Philosoph spricht über Sozialdemokratie und Migration“; jf. også hans sympati for arbejderbevægelsen i 1800-tallet, Ausgewählte Übertreibungen, 313: den var baseret på en følelse af stolthed, jf. om thymos sidst i artiklen her), hhv. 'oplysnings-konservativ' (Du musst dein Leben ändern, 17). Ikke mindst i betragtning af den gennemgående optimist-futuristiske holdning til tekniske nybrud, herunder genterapi, er rubrikken 'konservativ' uden yderligere kvalifikationer efter min mening misvisende.

42 Ausgewählte Übertreibungen, 233.

43 Identifikationen af det runde og det gode: Im Weltinnenraum des Kapitals, 20.

44 Die Sonne und der Tod, 219.

45 Im Weltinnenraum des Kapitals, 138-140. 
var ikke længere grundlæggelsesfortællinger, men fantasier om fremtidig gevinst; bekymringer angik ikke længere kun bevarelsen af etablerede tilstande, men blev mere og mere rettet imod den fremtidige gevinst ved risikovillige investeringer. Herefter var det subjektive ideal ikke længere tilbageholdenhed og selvkontrol (som det var i både de arkaiske religioners ritualer og i den aksiale askeses principielle bortvendthed fra verden), men det omvendte: hæmningsløshed ${ }^{46}$, utøjlet begær, anerkendt ret til at rage til sig og beundring af dem for hvem det lykkes. Sikkerhed - immunitet - søgtes herefter ikke opnået ved appeller til guddommelige magter, men ved forsikringssystemer (hvis hidtidige kulmination er post-kristne velfærdsstater og pensionsordninger til alle) ${ }^{47}$ Globaliseringen gennemførtes i høj grad af vovehalse, 'kaptajner', der kunne sejle ud, rage til sig i en værgeløs 'ny' verden, og vende rige tilbage. De, og deres investorer, satte ikke længere deres lid til en guddom som opstillede regler for anstændig adfærd og som sanktionerede i efterlivet; de troede på Lykken, Fortuna, det heldige tilfælde, som gav ekspeditionen succes. Eftervirkningerne af denne (verdenshistorisk nye) mentalitet vil Sloterdijk se i den nutidens tro på heldet der driver masserne til Lotto og andre spil. Det er blevet alment accepteret at drømme om at blive rig uden at have gjort sig anstrengelser eller gjort sig fortjent til det. ${ }^{48}$

Denne fase af globaliseringens historie afsluttedes omkring Anden Verdenskrig. Herefter var der geografisk ikke meget at opdage. Samtidig indtraf en modsatrettet bevægelse. Initiativerne der fører frem til den nutidens globale tilstand, udgår i mindre grad fra Vesten, men overtages af de tidligere 'opdagede' der nu tilkæmper sig magt til at reinvadere Vesten - om ikke militært, så med kultur og religion, kapital og mennesker. I midten af det 20. årh. var den 500-årige periode af ubekymret grådighed efter andres værdier - deres råstoffer, menneskekroppe, produktive landområder - forbi. Den ikke-vestlige verden kunne fra nu af gøre tilstrækkelig

46 Im Weltinnenraum, 93-107: Moderne subjektivitet etableres som den tillærte evne til at modstå egne hæmninger (det er altså ikke friheden, der er primær, men hæmningerne).

47 Forsikringsvæsenet er religionshistorisk relevant fordi det erstatter de religiøse sikringsforsøg, inkl. kult, gudstjenester og gode gerninger, med accept af risici. Snarere end at tale om et 'risikosamfund' vil det derfor være nærliggende at tale om et 'forsikrings-samfund', hvor forsikring også omfatter en social dimension (i form af socialstat, A-kasse etc.) og en medicinsk-hygiejnisk dimension (Sphären II, 885-900). At forsikring er tilstrækkeligt (“Versicherung schlägt Evidenz", ibid., p. 899) er et godt eksempel på nutidsmenneskers mangel på forventning om at opnå 'sandhed' eller 'mening'.

48 "Fortunatus und Taugenichts lassen bestens grüssen" ('Fortunatus [han som er elsket af Fortuna med en uudtømmelig pung] og Døgenigt sender deres bedste hilsener') (Ausgewählte Übertreibungen, 229). 
modstand. ${ }^{49}$ Den principielle hæmningsløshed er (hos nogle) afløst af en ny erkendelse af det gavnlige ved hæmninger og tilbageholdenhed. ${ }^{50}$

Globaliseringen var uden tvivl udtryk for en indbygget trang til ekspansion, som er virtuelt til stede i de fleste sociale organisationer (men som ofte også bliver tøjlet af modsatrettede kræfter, eller af omgivelsernes modstand). Opdagelses- og handelsrejsende, missionstiltag, videnskabelige ekspeditioner og statsstøttet, territorial imperialisme har været bevidste og planlagte projekter. Men globaliseringen som overordnet fænomen, inklusive dens resultat, den nu globaliserede verden, er ikke planlagt af nogen. Den er et faktum der 'er sket', en irreversibel tilstand som ikke har eller kan få nogen legitimation - ikke kun ingen religiøs legitimation, men heller ingen filosofisk: 'Som en anden natur eller som en skæbne retfærdiggør den sig ikke for nogen kritisk instans'. ${ }^{51}$

\section{Postoplysning}

Udgangspunkter for Kritik der zynischen Vernunft var krisen eller opbremsningen i forhold til tanken om oplysning - altså det centrale begreb i vestlig tænkning siden midten af 1600-tallet. Pointen er ikke at denne opbremsning skulle være noget der er indtrådt specielt eller først i filosofien - den er et socio-psykisk faktum i den nutidige flertalsmentalitet som ramte praktisk tænkning i form af politik og offentlig etik. Virkeligheden blev for omfattende til at tanken - den teoretiske som den praktiske kunne omfatte den. Politik i det 20. årh.s anden halvdel gik fra at være ledelse imod fremtids fjerne, men strålende mål til at være hektiske lappeløsninger og digebrudsreparationer. ${ }^{52}$

Den klassiske filosofi blev allerede i det 18.-19. årh. for en stor dels vedkommende tømt for sit traditionelle indhold der blev overtaget af selvstændige akademiske felter: fysik, historie, antropologi, psykologi etc. Fra og med kommunismens kollaps - der mentalt blev endeligt anerkendt omkring 1980, med 1970'ernes universitetsmarxisme som den træge bagtrop - var al 'stor' tænkning undermineret, for marxismen var den sidste globale, fremskridtsrettede oplysningstænkning..$^{53}$ På den ene side accepterer Sloterdijks egen tænkning de historiske vilkår for udviklingen af filosofi. Han forsøger altså ikke at 'løse' tænkningens problemer ved at 'regredere',

49 Man kan tilføje, at den post-vestlige tilstand på det religionsvidenskabelige felt tidligt blev registreret af Mircea Eliade, der i 1961 argumenterede for religionshistoriens nye relevans fordi "the peoples of Asia have recently reentered history ... the peoples of the West are no longer the only ones to 'make' history" (Eliade, 1961, 2). Med at 'genindtræde i historien' tænkte Eliade givetvis både på afkoloniseringer som fx i Indien og Pakistan i 1947 og på Japans militære ekspansion fra 1890'erne og frem til nederlaget i Anden Verdenskrig i 1945.

50 Im Weltinnenraum, 23.

51 Sphären II, 979.

52 Die schrecklichen Kinder der Neuzeit, 93; jf. Baunvig \& Lundager Jensen 2016.

53 En privat anekdote som eksempel på resterne af militant oplysningstænkning blandt studerende ved Aarhus Universitet i 1970'erne: Sovjetunionens militære invasion af Afghanistan i 1979 blev af en medstuderende hilst velkommen, fordi de lokale så endelig kunne komme til at lære at læse og skrive. 
ved at gå tilbage til en tidligere form for tænkning. En længsel tilbage til tiden før den franske revolution, til Montesquieus, Voltaires, Diderots og Humes tid og tænkning, vil være lige så futilt som en længsel tilbage til religiøs absolutisme. Traditionel tænkning er så fortidig at det ikke engang er relevant at vise på hvad måde den skulle være irrelevant; i dén forstand er Sloterdijks standpunkt postdekonstruktivistisk. ${ }^{54}$ Men på den anden side accepterer han oplysningens krise som et vilkår. For nationalistiske, kommunistiske og fascistiske udskejelser var lige så naturlige og, kunne man næsten sige, 'legitime', resultater af oplysningen som den franske revolutions jakobinisme og det borgerligt-liberale demokrati. Som marxister bør medgive at leninistiske, stalinistiske og maoistiske rædsler lå i faktisk kontinuitet med Marx, ${ }^{55}$ således bør oplysningsideologer medgive at både marxistiske og fascistiske rædsler var i kontinuitet med 1700-tallets oplysning. Evnen til at snakke uden om alting er ganske vist et af de moderne menneskers særlige styrker; 56 men alligevel har det været svært at få folk til at tro på at post-religiøs oplysning og totalitarisme ikke skulle have noget med hinanden at gøre.

En naiv oplysningsnostalgi, som man kunne kalde det, vil være irrelevant fordi oplysningsbremsning som historisk faktum er mere relevant. Oplysningen var som bekendt et frigørelsesprojekt. Med Kants velkendte formulering skulle menneskeheden afkaste sig de selvpålagte lænker, dvs. menneskene skulle erkende at de selv havde lænket sig til traditionelle tænkeformer (primært religiøst-dogmatiske) og sociale ordninger (stands-, kaste- og klassesamfund) som ikke havde noget tvingende nødvendigt ved sig ved - $\mathrm{fx}$ at være etableret af en guddom eller være indskrevet i tingenes orden. Erkendelsen af at ordningerne var menneskeskabte, var nøglen til forandringer: For hvad mennesker 'selv' har skabt, kan de også lave om. Ud fra en sådan frihedens position kunne man kritisere traditionen, primært religion - der inkarnerede og symboliserede 'lænkerne' - men også, i princippet, alt andet. Men den proces der hermed blev sat $\mathrm{i}$ gang, viste sig at være fundamentalt ambivalent $\mathrm{i}$ det som i Frankfurterskolen blev kaldt 'oplysningens dialektik' ${ }^{57}$ Den frembragte realiteter som det store flertal af mennesker i nutiden (forkælelsesvæsener som de jo er) stadig betragter som indiskutable og uundværlige goder: navnlig materielle goder, i kraft af tekniske revolutioner, fra smertebedøvelse over gulvvarme i badeværelset til antibiotika og smartphones, men selvfølgelig også immaterielle goder: sociale, juridiske, politiske, videnskabelige. Men den frembragte også onder i et omfang der kan forekomme at opveje eller overgå goderne: maskinel masseudryddelse af mennesker såvel som eksponentiel befolkningsvægt langt ud over klodens resurser, biologisk massedød, klima- og atmosfæreforgiftning. Goderne er imidlertid normalt nære og mærkbare, onderne normalt fjernere, i tid (Verdun, holocaust), i rum (afrikansk overbefolkning), ved at være gemt nådigt væk (nukleare våben, svine- og

54 Die Sonne und der Tod, 220.

55 Marx' tænkning indeholdt ikke eksplicitte forhindringer imod at blive omsat til totaliserende politik - den kunne vanskeligt hævde ikke at være 'af denne verden'.

56 Die schreckliche Kinder der Neuzeit, 335.

57 Jf. Horkheimer \& Adorno, Oplysningens dialektik (tysk Dialektik der Aufklärung, Fischer 1969; dansk oversættelse ved Per Øhrgaard, Gyldendal 1972). 
kyllingefabrikker), ved kun at vise sig langsomt (temperaturstigning) eller indirekte (artsudryddelse). For oplysningen at se var tiden inde til at menneskene overtog ledelse af sig selv. Men denne form for 'humanisme' har altså problematiseret sig selv. Det kan have været slemt nok for menneskerne, så længe de skulle trælle under deres selvskabte guder eller selvskabte Gud. Men gudernes eller Guds herredømme var mere nådigt over for kloden og alle andre levevæsener, end menneskenes har været, i hvert fald til nu.

'Prisen' for oplysning og kritik af traditioner viste sig først på det politiske felt, længe før den viste sig på teknisk-materielle felt. Afviklingen af standssamfund, statsabsolutisme og religiøst tyranni slog hurtigt - målt med historiens alen - om i den franske revolutions blodrus. ${ }^{58}$ Allerede her slog 'kærligheden til viden' (filosofi) om i den 'vilje til magt' som først fik sit rette navn af Nietzsche, et lille hundrede år efter. Det store flertal af nutidsmennesker befinder sig derfor i en tilstand af permanent rådvildhed. De (vi) er ikke villige til at opgive de moderne materielle og immaterielle bekvemmeligheder, og de betragter dem fortsat som irreversible fremskrift og velerhvervede rettigheder. Men prisen for dem er også alt for velbekendt. Den udbredte mangel på oplysningsentusiasme opvejes af en tilsvarende ulyst til teknologisk-kulturel regression og af manglende overbevisning om troværdige alternativer. Filosofien er generelt kommet længe efter den psyko-sociale realitet. Nietzsche blev uberettiget berømt ved at erklære Guds død - NB: efter at det for længst var blevet et trivielt faktum i det europæiske borgerskab. ${ }^{59}$ Og Kant definerede oplysningen som det at bryde bevidsthedsmæssige lænker, 300 år efter at fortøjningerne af skibene i de europæiske Atlanterhavshavne til den gammelkendte jord blev kastet og kaptajnerne overgav sig til den post-kristne gud Fortuna - hvorefter den reelle globalisering med dens cirkulation af mennesker og værdier, dens investeringer, risici og gevinster, satte ind.

Sloterdijk er altså ikke oplysnings- eller frigørelsestænker eller 'kritisk' filosof i normal forstand. Dels, som historien har vist, er det et alt for risikabelt projekt at hensætte sig i en principiel 'kritisk' position der pr. def. ville være en quasi-religiøs gudserstatning. Den forudsætter et overblik og en evne til at gennemskue (og en viden om hvad de bedre alternativer til det kritiserede skulle være), som det netop har været tænkningens opgave efter totalitarismernes fallit at lære at lade være med at tillægge sig selv. Formålet med tænkning og skrivning kan heller ikke være at forklare at lykken ligger længere henne ad tidens vej; det vil forudsætte at vejen dertil pr. def. må være mere eller mindre ulykkelig, dvs. at de nuværende mennesker som en slags histories martyrer eller ofre lider og ofrer sig for de fremtidige, lykkeligere generationer. ${ }^{60}$ Men formålet kan heller ikke være en kultur-masochistisk jammer

$58 \quad$ Kritik der zynischen Vernunft, 8.

59 Jf. Über die Verbesserung der guten Nachricht, 54.

60 Den ekstreme russiske udgave af denne tankegang, der var inspireret af Nikolaj Fjodorovs kristenutopiske tanker om alt menneskeligt livs genopstandelse (sic!), og som udfoldede sig som biokosmisme og ontologisk utopisme i tiden før og efter den russiske revolution, mundede (kun tilsyneladende paradoksalt) ud i beslutsom politisk 'eksterminisme', vilje til at slå ihjel i stor stil. Den le- 
over nutiden eller opbyggelse og opretholdelse af selvundertrykkende skyldkomplekser over forfædres forbrydelser og egne undladelser.

Er Sloterdijk da ikke en typisk 'postmoderne' tænker? Selv om samtidsdiagnosen ligner den som man finder hos en fransk tænker som Jean-François Lyotard, der gjorde begrebet om det postmoderne kendt, vil Sloterdijk ikke gå med på at det, som Lyotard kaldte de store fortællingernes tid - oplysningens, marxismens, frigørelsens - skulle være ude. ${ }^{61}$ Det er muligt at $\mathrm{fx}$ religionens og filosofiens historie er ude (altså som dominerende og retningsgivende forestillingskomplekser og normsystemer for mange mennesker og hele samfund). Men videnskabens og teknikkens historie er som bekendt overhovedet ikke forbi. Og selv om den menneskelige ekspansion på Jorden er tilendebragt i den forstand at Jordens rundhed er blevet gjort til praktisk virkelighed med cirkulationen af varer, penge, informationer, mikrober og nu også menneskemasser, fortsætter den tekniske ekspansion i alle retninger.

At tale om historiens standsning er også problematisk fordi den kan give illusion af at historie som sådan er mindre relevant eller interessant for at forstå nutiden. ${ }^{62} \mathrm{I}$ Sloterdijks værk er det lige omvendt. Mange af hans titler er i større eller mindre omfang variationer af en og samme sag, fortællingen om tilblivelsen af nutiden. Bogen Kritik der zynischen Vernunft er også en historie om hvordan oplysningen bremsede op og blev stillet over for valget imellem dagligdagens kynisme og marginal-kunstnerisk græsk kynisme. Sphären I-III er bidrag til den meget lange historie om menneskehedens selvudvikling fra de biologisk givne primær-rum (livmoder, yngelpleje) til nutidens boligkomplekser, indkøbscentre, sportsarenaer og rumstationer. De religionsteoretiske skrifter er historier fra aksetid til nutid om former for kulturel omgang med vrede, zelotisme og askese. Og Die schrecklichen Kinder der Neuzeit (2015) er historien om hvordan mennesker i før-moderne samfund (overalt) skulle se tilbage i solidaritet med deres forældre og disses forældre - og hvordan de i det moderne gør deres eget liv meget besværligt hvis de mener at de fortsat bør gøre det. Oplysningens tid er blevet til afklaringens tid. ${ }^{63}$ Sloterdijks tænkning forklarer ikke hvordan verden skal laves om, men fortæller hvorfor den er blevet som den er; det er altså tid til historie.

\section{Eksplicitering}

Post-oplysning if. Sloterdijk indebærer hverken ignorering af historien - som forbliver den indlysende vej til at forstå hvorfor tingene er som de - eller en forestilling om at historien ikke går videre. Når den heller ikke indebærer en reaktionær nostalgi, hænger det sammen med det beslutsomt evolutionære ved Sloterdijks historie-

ninistisk-stalinistiske krig imod befolkningens masser var en mere praktisk gennemførlig udgave af utopisternes ønskede krig imod naturen (Du musst dein Leben ändern, 557, 622-33).

61 Im Weltinnenraum des Kapitals, $12 \mathrm{f}$.

62 Til historiens svage stilling i religionsvidenskaben, trods det overleverede begreb om en 'religionshistorie', jf. Klostergaard Petersen \& Lundager Jensen, 2013.

63 Ausgewählte Übertreibungen, 420f.

20 Hans J. Lundager Jensen 
forståelse. Oplysning lader sig bedre forstå som eksplicitering, altså tydelig-gørelse, blot-læggelse, ud-foldelse. ${ }^{64}$ Modernisering er uddifferentiering (fra arbejdsdelingen if. Durkheim over Webers adskilte rationalitetssfærer til Luhmanns subsystemer), og uddifferentiering er eksplicitering: Hvad der før var underforstået, bliver nu lagt for dagen. I traditionelle religioner var ret og retfærdighed, skønhed, ekstase og økonomi filtret ind i hinanden. I et nutidigt samfund går man til domstolen for at få retfærdighed, til kunsten for at få skønhed (eller, måske mere nutidigt, nydelsesfuld hæslighed), til megakoncerter eller til ens pusher for at få ekstase, og til bankrådgiveren for at høre om man har råd til det. Pornografien har i samme forstand gjort det eksplicit at kærlighed og seksualitet i grunden ikke er det samme.

Begrebet oplysning som metafor for moderniseringen som proces er problematisk af flere grunde. Det var et religiøst begreb der blev usurperet af den antireligiøse sekularisme. ${ }^{65}$ Dertil kommer at graden af uoplysthed i verden vokser i takt med dens faktiske oplysthed. ${ }^{66}$ Et godt billede på den ubestridelige erkendelsestilvækst som er indeholdt i oplysningen, finder Sloterdijk i de anatomiske opdagelser fra og med 1500-tallet, hvor menneskets indre bliver beskrevet og forstået - dvs. hvor det der var implicit herefter er blevet eksplicit: blotlagt, synligt, ubestrideligt. Pointen er at denne proces - begyndende med den anatomiske at sprætte en menneskekrop op, se ind i den og forstå hvad den består af og hvordan delene fungerer dels bliver et paradigme for moderne tænkning, dels er irreversibel, og dels frembringer en mængde nye spørgsmål, dvs. gør menneskene uvidende på et højere plan (fx: Hvad tjener alle disse hidtil ukendte organer til? Hvordan fungerer de?). Den hidtil i bogstavelig forstand skjulte hemmelighed om menneskets indre er sluppet ud; det lader sig dårligt gøre at skubbe indvoldene tilbage, sy liget sammen og lade som ingenting. Man kan evt. beklage den voksende viden; men det er svært at ignorere den, endsige udslette den. Tilsvarende udtrykker arkitektur i det 20. årh. en tydeliggørelse af hvad det egentlig vil sige 'at bo': eksplikationen af menneskeligt ophold i menneskeskabte interiørs (jf. nedenfor om de ni topoi) ${ }^{67}$ Kommunikation er ikke det samme som nærvær, for nu kommunikerer man hellere med fraværende end med nærværende mennesker. Historien er altså så langt fra at være hverken reversibel eller stoppet op at der tværtimod vil være flere ekspliciteringer i vente, og det vil vise sig at det man fortsat naivt tror hører sammen, egentlig er helt forskellige ting.

\section{Vertikalitet}

Som sagt er figuren 'skum' god at tænke med fordi den er tredimensional og inviterer til at forestille sig virkeligheden som et rum med mange elementer der både er

64 Sphären III, 69f.; Ausgewählte Übertreibungen, 244.

65 Der ästhetische Imperativ, 94-99.

66 Der ästhetische Imperativ, 116; som eksempler på felter, black boxes, med stor oplysningsresistens eller stigende mørke-modstand anføres døden, kroppen, bogen, bureaukratiet og maskinen (hvad foregår egl. inde i en smartphone?).

67 Sphären III, 501. 504. 
isolerede fra hinanden og dog grænser op til hinanden. Den egner sig altså godt som billede på kulturel evolution. Figurens fordel er at den indebærer vertikalitet: Skum vokser ikke kun i bredde og dybde, men også i højde. Faktisk er menneskehedens historie bestemt af en stræben både udefter og opad, fra de første hominiders oprejste gang til nutidens stadig voksende skyskrabere og rummissioner. Megen postmoderne tænkning, der ellers har mange lighedspunkter med Sloterdijks, insisterer nok på virkelighedens kompleksitet og elementernes inkommensurabilitet - i kulturvidenskaberne fx ved fokusering på kulturelle eller religiøse forskelle frem for ligheder og ved mistænksomhed over for at bruge almenbegreber der antages at fratage de enkelte fænomener deres individualitet. ${ }^{68}$ Men dermed risikeres fænomenerne at blive nivelleret på en anden måde, for beskrivelserne etablerer en kunstig samtidighed som gør det umuligt at forstå hvorfor nogle kulturelle formationer har kunnet dominere og vokse, mens andre er forsvundet, skrumpet ind eller ikke selv har kunnet vokse. Kulturel evolution er en læreproces, ${ }^{69}$ og nogle kulturelle systemer har (på godt og på ondt) lært mere eller hurtigere end andre. Og så har man afskåret sig fra forstå den menneskelige trang til at bevæge sig opad som ellers skulle være svært at ignorere, fra pyramiderne i 3. årt. f. Kr. til nutidens kilometerhøje skyskrabere, og til flyvemaskiner og rumfartøjer. ${ }^{70}$ Trangen til at være noget andet end det man er, til at ændre på sine egne livsomstændigheder (ofte imod ens egne forestillinger om hvordan man burde leve og verden burde være), kort sagt den kulturelle evolution, kan kun forstås ved at forstå de fundamentale træk der gør at mennesker er netop mennesker og ikke nogen som helst anden slags organisme dvs. igennem en lære om mennesket, en antropo-logi. Og igennem denne udvikler Sloterdijk så det historisk mere oprindelige begreb om askese, 'træning, øvelse' som udfoldes i bredden og højden i bogen Du musst dein Leben ändern. Asketen er den som kan sige nej til det meste for at kunne nå højere op eller længere ud end han eller hun tidligere kunne, eller som gør det til et projekt at forblive deroppe eller derude. Og alle mennesker er i grunden, om de vil det eller ej, vertikalt udfordrede, dvs. asketer, for de kan ikke lade være med at træne og øve sig, om det så er i de mest trivielle rutiner.

\section{Anti-miserabilistisk antropologi}

En af inspirationskilderne til Sloterdijks antropologi er den tyske filosofi Arnold Gehlen (1904-1976) og dennes begreb om 'aflastning' (Entlastung). $\cdot^{71}$ Mennesket er en biologisk art som andre arter; men det særlige er dets trang til at skaffe sig selv lettelser: Mennesker frembringer tekniske hjælpemidler til at udføre hvad kroppen ikke selv kan (fx ramme mål på afstand, transformere fødevarer fra vanskelig til

68 I religionsvidenskaben kan man som eksempel tage Clifford Geertz' $(1973,122)$ afvisning af relevansen af klassifikatoriske samlebegreber som animisme, totemisme, shamanisme til fordel for tætte beskrivelser af individuelle kulturers religioner og disses individuelle ytringer.

69 Ausgewählte Übertreibungen, 36.

70 Jf. Das Schelling-Projekt, 186: 'af al evolution er det i sidste instans kun vingerne der er interessante'.

71 Ausgewählte Übertreibungen, 215. 
lettere fordøjelig form), hjælper sig selv imod stressfaktorer ved hjælp af magi og opbygger institutioner til at varetage essentielle funktioner. Samtidig følger Sloterdijk ikke Gehlen i at bestemme mennesket som et 'mangelvæsen', dvs. en biologisk art som er ringere udrustet end så mange andre dyrearter. If. Gehlen var kultur (i bred forstand) opstået som kompensation for de mange mangler. ${ }^{72}$ Sloterdijk vender forholdet om. Ingen art 'mangler' noget, heller ikke menneskenes biologiske forfædre. Mennesket er grundlæggende ikke det væsen der mangler noget, men det der giver og frembringer noget. Menneskets er som sagt et forkælelsesvæsen, også kaldet et 'overskudsvæsen', et 'luksusvæsen'73. 'Aflastning' er ønske om luksus; og historien viser den accelererende komfort og lettelse af tilværelsen. Men det er måske først i anden halvdel af det 20. årh. at denne tendens til at gøre sig livet behageligt slår igennem for så mange mennesker ${ }^{74}$ at den er blevet tilstrækkelig synlig.

Dette er i øvrigt Sloterdijks bud på 'hvad der skete i det 20. årh.?', dvs.: Hvad den vigtigste begivenhed var i det forgangne århundrede. Det var at en stor del af menneskeheden kom til at leve i materielle forhold (føde, varme, tryghed, frihed for smerte, sygdom, hårdt fysisk arbejde, muligheder for at bevæge sig i rummet, tilegne sig viden, opnå underholdning) som selv konger og fyrster i fortiden kun kunne drømme om. Men det lette liv (der har trukket den 'postmoderne' følelse af svæven og svimmelhed med sig) er kun kommet til i kraft af en kulturel og teknisk evolution hvis første begyndelse kan ses i de mest enkle redskaber, bemestring af ild og effektiv kommunikation med artsfæller og som er endt med at enorme befolkningsgrupper, rige og de fleste fattige, kan leve det luksusliv at bo i opvarmede boliger og kunne spise kød - takket være udbytningen af fossile energikilder og et kolossalt dyre-slaveri. ${ }^{75}$

En paradoksal konstans er så ganske vist den ret uniforme benægtelse af det indlysende faktum. For at blive taget alvorligt som tænker er det fortsat en fordel at tale verden og menneskeheden ned, ikke op. Den grundlæggende indstilling at tage goder som overfladefænomener og elendigheder som dybe sandheder betegner Sloterdijk som miserabilisme. Dens rødder rækker tilbage til aksetidens forkastelse af 'Verden'. Dens klassiske kristne udtryk er en bog af Lotario de Segni (den senere berømte pave Innocens III), De miseria humanae conditionis ('Om den menneskelige tilværelses elendighed ${ }^{\prime 76}$ ) fra ca. 1160, et læseværdigt rædselskatalog over den menneskelige tilværelses jammerligheder, fra fosterets dannelse i ekstremt ulækre sub-

72 At kultur skulle være erstatning for manglende naturlige egenskaber, kan genfindes i Clifford Geertz' ide om symboler (tegn, sprog) som udbedring af et genetisk betinget instinkt-deficit (1973, 92f.).

73 Sphären III, 701; 'luksusvæsen': ibid. 706: 'Homo sapiens (...) er ikke et mangelvæsen som kompenserer for sin fattigdom med kultur, men et luksusvæsen som i kraft af sine protokulturelle kompetencer var tilstrækkeligt sikret til at overleve alle farer og lejlighedsvis også at blomstre og udfolde sig'. Jf. Der ästheische Imperativ, 261: 'homo sapiens er konstitutionelt ude af stand til at være fattig'.

74 Der er utallige for hvem livet endnu ikke er ret behageligt; men det skandaløse ved den endnu eksisterende elendighed er netop at så mange endnu ikke er lukket ind i overflodens comfort zone.

75 Was geschah im 20. Jahrhundert?, 93-136.

76 Også med den lige så træffende titel Liber de contemptu mundi, 'En bog om at foragte verden'. 
stanser og til tidlig død eller savlende senilitet. ${ }^{77}$ Vigtigere er dog miserabilismens sekulariserede udgaver i mange skikkelser. Hvad der typisk har adskilt venstre- fra højre-tænkning har været de foretrukne tiltag, imod fremtids fjerne mål eller tilbage til tidligere og solidere tiders idealer. Hvad de har været enige om, er at verden må og skal forandres, fordi den, og dermed menneskene i den, er langt fra at leve op til de forventninger som de respektive tænkere mener at man med rimelighed kan forlange af den. At en stor del af menneskeheden efter alle rimelige historiske målestokke faktisk er velstående, velhavende, rige, at de lever i en overflod og en sikkerhed som tidligere kun kunne forbindes med guddomme, er en bitter pille at måtte sluge. ${ }^{78}$

'Luksusvæsen' betyder ikke kun et væsen som gerne vil befinde sig i luksuriøse sfærer, men også et væsen som hengiver sig til luksuriøse aktiviteter, dvs. bruger sin fysiske og mentale energi på formål der ikke umiddelbart har noget håndgribeligt afkast. Fantasi er et luksus-fænomen. Mennesker registrerer ikke kun hvad der er tilfældet, eller planlægger taktisk hvordan det skal opnå umiddelbare goder eller undgå nærliggende farer - det frembringer også forestillinger om tilstande og hele verdener der ikke svarer til deres erfaringer. Det ligger altså også til luksusvæsenet at ud-trykke og ud-folde sig - ikke mindst, og måske navnlig, ved at skabe rum, sfærer, omkring sig. Men da al udfoldelse sker med de materialer og de forudsætninger der står til rådighed på et givet tidspunkt, vil menneskenes udfoldelser bestå i en evolution - en ud-rulning (latin evolutio af e-volvo af ex-volvo, 'rulle ud') snarere end en frem-ad-rulning.

Nogle mennesker er givetvis bedre til at folde sig ud end andre. De fleste vil være tilfredse med at befinde sig i den allerede opnåede sfære. Derfor er der hos Sloterdijk også en særlig interesse for, og sympati med, de særlige talenter på et givet tidspunkt, altså, om man vil, en 'elitær' og Nietzscheansk tone. Den mest indlysende elite-markering er (igen) i graden af vertikalitet. Der er højdespringere og bjergbestigere, bogstavelige og metaforiske, og så de mange andre. Spændinger og konflikter imellem masse og enere vil være uundgåelig. Aktuelt bør massekultur ses som et anti-vertikalt fremstød hvor tidligere tiders oplagte (berettigede eller uberettigede), vertikale forskelle på fin og ikke-fin, høj og lav, fremragende og middelmådige, gerne horisontaliseres til sideordnede, svage og reversible forskelle (et nutidigt dansk eksempel: at der er flere TV-seere til amatører - sangere, dansere og bagere end til dygtige og professionelle udøvere). Hvis alle er forskellige, bliver det svært at legitimere kvalitative skel imellem bedre og ringere, dygtigere og mindre dygtige. Heroverfor kan Sloterdijk (med henvisning til den rumænsk-franske forfatter Emil

77 Sphären III, 680. - Refleksionerne over fostertilstanden og spædbarnets normalt omsorgsfulde modtagelse til tilværelsen i Spären I kan læses som en storstilet afvisning af netop de Segnis sortmaleri (Sphären I, 301); i det hele taget er der i forfatterskabet en polemisk front imod principielle pessimister, sortseere, nedtalere, sammenfattet i termen 'problemoholikere' (Kritik der zynischen Vernunft, 249). En prominent neo-miserabilist var den berømte franske sociolog Pierre Bourdieu, der i 1993 redigerede en bog med titlen La Misère du monde, 'Verdens elendighed' (Sphären III, 680. 805).

78 Menneskene er godt udstyret med hensyn til evne til at konstatere hvad der er tilfældet, og til at håbe på hvordan tingene kan blive, men mindre godt udrustet mht. at vurdere hvordan tingene kunne have været (Ausgewählte Übertreibungen, 309). 
Cioran) anbefale at gøre sig umage med at beundre det man ikke selv er i stand til at frembringe, og dermed den der har frembragt det. ${ }^{79}$ Selv om fortællingen om den kulturelle evolution nødvendigvis også må indeholde fejlgreb og selvovervurderinger, bliver den uforståelig hvis den forvrænges til en kæde af tåbeligheder. Sloterdijks mange varianter af fortællingen om hvordan og hvorfor tingene er blevet som de er nu, er i høj grad en sådan beundringens historie.

\section{'Sociologi'}

Sloterdijk advarer som ovenfor anført imod begrebet 'samfund' - det underforstår en homogen, konstant og beskrivelig størrelse og forleder os til at tro at vi allerede ved hvad der konstituerer forhold imellem mennesker, og fordi den lyder for meget af typisk sociologiske forestillinger om sammenhængende interaktioner mellem mennesker. ${ }^{80}$ Den sociale virkelighed er langt mere kompleks, dynamisk og uoverskuelig - alt dette som billed-begrebet 'skum' skal kunne give indtryk af. I overensstemmelse med sin generelle taktik med at omskrive det for let forståelige med mere uvante og mere refleksionsfremmende termer foreslår Sloterdijk mange forskellige om- og re-formuleringer, fx 'tilfælde/instanser af anvendt sfærelogi', ${ }^{81}$ 'urolige og asymmetriske forbindelser af rum-mangfoldigheder og proces-mangfoldigheder hvis celler hverken kan forenes eller være adskilte', ${ }^{82}$ 'et bekymringsfællesskab bragt svingning af stresstemaer'.$^{83}$

Heldigvis kan sådanne abstrakte bestemmelser gøres mere konkrete. Det sker bl.a. i en længere fænomenologisk beskrivelse af menneskelige rumdannelser ${ }^{84}$ Det ligger som sagt til menneskene at de skaber rum omkring sig - antropotoper (dvs. 'menneskesteder'). Et sådant menneskested vil være et rum, tópos, inden for hvilket der kan leves, altså en 'bio-top' (ordret: 'livs-sted'), og det på mindst ni forskellige måder (hver navngivet ud fra græske eller latinske termer). ${ }^{85}$ Det må være (1) en kiro-top (hånd-sted), et rum som rummer mulighed for at række hånden ud og gribe ting, kaste, slå, skære i; mennesker er pattedyr hvis poter er blevet til hænder hvormed deres materielle omverden kan ændres og deres (fremtidige) sociale verden organiseres, frem til knivens fordeling af et offerdyr; ${ }^{86}$ (2) en fono-top (lyd-sted), dvs. et soundscape, en klanginstallation hvor mennesker omgives af lyd, hvor der udsen-

79 Die Verachtung der Massen, 85f. 94f.

80 Jf. Sloterdijks samtalepartner Bruno Latour (2005), if. hvem et (substantielt) begreb om 'samfund' (dvs. som en slags beholder) ligefrem er en forhindring for at forstå hvad det sociale er. - Sloterdijk må derfor forsøge sig med alternative betegnelser, fx, som i Zorn und Zeit 339f.: 'solidar-fællesskab', 'overlevelsesenhed'.

81 Sphären II, 1007.

82 Sphären III, 57.

83 Stress und Freiheit, 38.

84 Sphären III, 361-490; Der ästetische Imperativ, 245.

85 En (velillustreret!) sammenfatning i en større publikation om fremtidens badeværelser kan ses på internettet: Schreiber 2013.

86 Sphären III, 377 - altså en urgammel metafor der stadig er udtryksduelig, som i danske debatter om hvordan man skal skære 'velstandskagen'. 
des meddelelser, beskeder, forespørgsler, ytringer, men også lydlige velvære- eller lidelses-signaler, hvor der hviskes og tiskes, les og stønnes, hvor stemninger vækkes eller opretholdes af lyd: arbejdslyde, legende og skændende børn, snakkende voksne osv.; (3) en utero-top (livmoder-sted), det udvidede moderskød der forlænger fosterets første væskefyldte rum ude i det atmosfæriske jordsted ved at udgøre et familiært rum hvor man kan føle sig hjemme, omgivet af venligtsindede artsfæller; (4) en termo-top (varme-sted), som er et forkælelsesrum for luksusvæsener, fra bålet til de veltempererede drivhuse som mennesker nu foretrækker at bo, arbejde og lade sig transportere i, og til varmen som metafor for det gode samvær med andre; (5) en eroto-top (kærligheds-sted), et rum hvor begær efter genstande, status og andre mennesker udfoldes og flyder rundt og hvor misundelsen vækkes og, evt., holdes i ave med forbud og regler; (6) en ergo-top (arbejds-sted) hvor der udføres arbejder der er begrundet i fællesskabets interesse, også som deltagelse i krig, og hvor synkroniseret handling indøves igennem ceremonier; (7) aletho-top (sandheds-sted) eller mnemo-top (hukommelses-sted) der opbevarer og akkumulerer fælles viden om verden og sig selv, inkl. visdom og videnskab; en (8) en thanato-top (døds-sted), som også er en theo-top (guddoms-sted) hvor forfædre, guder og andre usynlige magter hersker; og endelig (9) en nomo-top (lov-sted) hvor regler for fælles handlen indøves igennem ritualer og arbejdsdeling - hvorved en gruppe etableres som en slags immateriel 'tensigritet', dvs. en rumlig konstruktion hvor helheden holdes oppe ved at de enkelte dele holder hinanden i spænd - 'samfundet' her ikke tænkt som en tung stenbygning, men som et udspændt telt med vibrerende ribber. ${ }^{87}$

\section{Etik, politik}

I Sloterdijks skrifter er det ikke svært også at læse en form for etik - hvordan bør man leve? - og en udvidet etik: politik - hvordan bør man leve sammen? Her kan skelnes tre faser: palæo-politik, kosmo-politik og hyper-politik.

I traditionelle samfund var etik identisk med at følge ens gruppes regler, og den tilsvarende palæo-politiks ${ }^{88}$ opgave var at opretholde gruppen over tid, evt. inklusive at udvide eller ændre gruppens råderum ved lokal ekspansion eller migration. I den egentlige globaliserings fase var den etiske opgave blevet at frigøre sig fra den lokale gruppes begrænsede normer og definere sig selv som beboer af en altomfattende kugle, altså, med kynikeren Diogenes, at blive en kosmo-polit, en person der har hele verden som sin 'by', sin 'polis'. Immanuel Kants etiske princip, at gøre universelle kriterier gældende for ens konkrete handlinger, er et sent eksempel på den kugleformede globaliserings etik. Den tilsvarende politiske opgave var at transformere kuglens, altså Jordens, indhold til en retfærdig og fornuftig orden. Den nuvæ-

87 Sphären III, 472f. - Gennemgangen af hver af disse topoi kan måske læses som respektive delfilosofier - beskrivelsen af nomotopen er således i en vis forstand Sloterdijks retsfilosofi eller retsfilosofiske skitse.

88 Im selben Boot, 14-26: de essentielle træk ved arkaiske fællesskaber (s. 16). 
rende fase har gjort disse former for megalomani og megalopati ${ }^{89}$ irrelevant. Politik må nu være hyper-politik, som forstår og respekterer skumboblernes uovervindelige trang til at danne og opretholde små sfærer inde i det store skum, altså lokale grupperinger af alle former, alle de slags 'samfund' som mennesker altid vil danne med sig selv (!) og med bestemte andre. Det tilsvarende personligt-etiske princip vil da være den opgave at danne og opretholde bobler af levedygtige rum med atmosfærer der kan åndes $\mathrm{i}$, med sig selv og med andre - og respektere andres ret til at gøre det samme. ${ }^{90}$ Man kan her søge hjælp hos eksperter. Den teoretiske globaliserings etik og politik blev udtænkt af filosoffer og teologer; den ekspansive globaliserings eksperter var opdagelsesrejsende og korttegnere; i skummets tid er eksperterne designere og arkitekter. ${ }^{91}$

Med baggrund i sin anti-miserabilistiske antropologi og i sit forsvar for selvregulerende sociale enheder har Sloterdijk foreslået at nytænke grundlaget for finansiering af staten, altså skattebetalingerne. ${ }^{22}$ Statens ret til at beskatte borgerne bliver normalt ikke begrundet og tages for givet, af staten såvel som af skatteborgerne; men de mest plausible legitimationer er formentlig en uklar kombination af den enevældige stats ret til at kommandere med sine borgere og en socialistisk forestilling om at al ejendom i grunden er tyveri, og at statslig beslaglæggelse derfor er et moralsk retfærdigt modgreb. Den passivitet og umyndighed blandt borgerne som er følgen af underskuddet af refleksion og begrundelse, foreslår Sloterdijk modgået med en omkategorisering af skat til at være borgernes generøse gave til fællesskabet. Forslaget har vakt voldsom kritik, enten som et argument for lavere skatter generelt eller som et udtryk for fantaserende, verdensfjern idealisme. ${ }^{93}$ Sloterdijk anerkender at stater må have indtægter som kommer fra deres egne borgere. Imod anklagen om naivitet anfører han at alternativet er en forestilling om den nødvendige tvang over uhelbredeligt egoistiske mennesker. Det politiske højre og det politiske venstre kan være fælles om en sådan antropologisk miserabilisme. Men al historisk erfaring viser at mennesket tværtimod grundlæggende er et socialt og generøst dyr som ikke kan lade være med at danne samfund, dvs. at give fra sig hvad det kunne have beholdt. Ganske vist vil et forsøg med frivillig skattebetaling så nok inkludere et træningsprogram i samfundssind for de rige. ${ }^{94}$

89 Sphären II 303 n. 130: 'megalopatisk fornuft er den ikke-psykotiske arbejdsform for politisk og ontologisk tænkning i imperiernes og deres metafysikkers tidsalder'; jf. Morin 2009, 68.

90 Im selben Boot, 80: 'Det hyperpolitiske samfund er et fællesskab af spillere som også i fremtiden vil satse på verdensforbedring: Hvad det skal lære, er at handle så der også - efter at det selv har sejret - kan komme andre vindere. Dette forudsætter at hyperpolitikken bliver til fortsættelse af palæopolitikken med nye midler'.

91 Morin 2009, 68.

92 "Die Revolution der gebenden Hand", artikel i Frankfurter Algemeine Zeitung 13. juni 2009.

93 En prominent kritiker var Frankfurter-filosoffen Axel Honneth: "Fataler Tiefsinn aus Karlsruhe", Die Zeit, 24. sept. 2009.

94 Die nehmende Hand und die gebende Seite; "Warum ich doch recht habe" (2010). 


\section{Religion}

Det giver sig af den generelle kulturevolutionære tænkning at der intet er som ikke er forberedt af noget tidligere, inklusive Sloterdijks egen tænkning og kulturanalyse. Klassisk filosofi og fænomenologi forudsætter metafysik og denne igen antikkens religioner. Fx vil Sloterdijks egen sfæriske antropologi anerkende at den er en 'elev af teologien' (en elev der ganske vist overgår sin lærerinde). ${ }^{95}$ Teologi i betydningen teologi-historie, historiske teologier, er så meget mere indlysende relevant som menneskevæsenets primære produktivitet består i at 'indkvartere sig selv i egensindige, surreale - altså over-naturlige, mere-end-virkelige, rumforhold'.$^{96}$ Teologiske forestillinger er i sagens natur og i bogstavelig forstand surrealistiske, og det taler ikke imod deres relevans. Tværtimod går surrealisme forud for realisme: først tænkes forhold i fantasmatiske termer, derefter kan de udmøntes som praktiske projekter eller som afklarede og nøgterne begreber. Fx munder Sphären I, undersøgelsen af mikrosfærerne og de stærke forbindelser som Sloterdijk bygger sin antropologi og sin 'sociologi' på, ud i analyser af tre traditionelle grundtemaer i den kristne teologihistorie: forholdet imellem sjælen og Gud, triniteten og Mariologien. ${ }^{97}$ Her formuleres paradokserne ved det ultra-intime livs karakter af at være inden i noget (er sjælen i Gud, eller er Gud i sjælen?) og de stærke forbindelsers resonansrum hvor relationerne imellem personerne er så tætte at de ikke med rimelighed kan kaldes 'individer' og dog alle har en egen-identitet. Den idehistoriske vej går her fra en forudgående mangel på opmærksomhed via surrealistisk fantasi til en mere principiel og virkelighedsnær formulering på den sekulariserede fornufts præmisser.

Som allerede dette eksempel viser, spiller religion en ganske betragtelig rolle i Sloterdijks forfatterskab. Man kan pege på flere gode grunde. For det første er kultur ikke mindst i før-moderne samfund ofte nogenlunde overensstemmende med religion. For et så kulturanalytisk og -historisk forfatterskab som Sloterdijks vil religion, hhv. religionshistoriske, kirkehistoriske og teologiske temaer, derfor uundgåeligt dukke op overalt; hvad der er filosofi, videnskab og tænkning i dag, har tidligere været religion og teologi. For det andet er der en ret klar inspiration fra aksetidsasketiske temaer i Sloterdijks egen Nietzsche-inspirerede tænkning ${ }^{98}$ - hvor askese og kreativitet lejlighedsvis akkompagneres af en vis 'østlig' accept af verden som den er. ${ }^{99}$ For det tredje er kapitalismen selv en slags religion, dvs. 'en way of life med ultimativ orienteringskraft og direktive emblemer (navne, varer) og opfyldt af en vis mængde messiansk energi' ${ }^{\prime 100}$ (deraf dens formodentlige stabilitet og overlegenhed i forhold til retro-religiøse modangreb). Og for det fjerde kunne religion, i hvert fald fra 00'erne, alligevel ikke ignoreres som en faktor i konflikter på globalt plan. At

5 Sphären I, 54.

6 Sphären I, 83.

97 Sphären I, 549-98; 598-631; 632-37.

98 Til aksetid generelt, jf. Religionsvidenskabeligt Tidsskrift 60, 2013. Begrebet 'aksetid' er hyppigt forekommende hos Sloterdijk, fra - eksempelvis - Kritik der zynischen Vernunft, 933, til Die schrecklichen Kinder der Neuzeit, 234.

99 Jf. fx Im Weltinneraum des Kapitals (2005), 101; Stress und Freiheit, 48.

100 Der ästhetische Imperativ, 164. 
islam kunne overtage det (efter kommunismens sammenbrud) ledige standpunkt $\mathrm{i}$ kampen imod den liberale, demokratiske og kapitalistiske nutid - og det med en energisk-emotionel kraft og hensynsløshed fuldt på højde med nationalisme, fascisme og kommunisme - kom helt uventet. ${ }^{101}$

Det er altså ikke så mærkeligt at Sloterdijk i lyset af 00'erne tilmed har viet religion nogle særlige religionsteoretiske publikationer. Hovedværket er den store bog Du musst dein Leben ändern, hvis inspiration primært er den anden af de ovennævnte grunde. Dertil kommer det mere overkommelige essay, Gottes Eifer: Vom Kampf der drei Monotheismen (2007). ${ }^{102}$ Bogen Zorn und Zeit (2008) med en længere teologihistorisk oversigt kan til en vis grad medregnes i det religionsteoretiske forfatterskab. Men i betragtning af hvor ofte religiøse og teologiske temaer drøftes, fra flygtige referencer eller emne til grundige redegørelser, kan alle Sloterdijks publikationer betragtes som også religionsteoretiske; de er i hvert fald alle religionsvidenskabeligt relevante. ${ }^{103}$

Termen religionsteori skal nok markere at der ikke er tale om religionsfilosofi i mere normalforstand, skønt grænsen nok er flydende og betegnelsen 'religionsfilosofi' for hans overvejelser også dukker op her og der. ${ }^{104}$ Men gennemgående i Sloterdijks omgang med religion er fremhævelsen af det essentielt irrationelle ved religion - dvs. det fantasmatiske, imaginære, surrealistiske. Fx kan præster kaldes 'eksperter i det ekstreme' (Sphären II, 952). En gennemgående tone er at mennesket er et væsen der i historien frigør sig fra det normalt-fornuftige ${ }^{105}$ og via kultur (i et langt stræk af menneskehedens historie i praksis = religion) frembringer en verden som man ville kalde surrealistisk - hvis det ikke lige var fordi den faktisk, igennem tekniske opfindelser, er blevet til virkelighed. Ikke alt 'surreelt' som mennesker har kunnet forestille sig, er selvfølgelig blevet til virkelighed; men meget er - fx at kunne tale med mennesker der ikke er i samme rum som en selv, at kun flyve, at kunne blive skåret i uden at føle smerte, at kunne opholde sig under vandet, at kunne flyve op i himlen og gå på månen og at kunne frembringe så meget mad til så mange at overfloden i sig selv er blevet et problem.

Derimod stiller Sloterdijk sig skeptisk over for kategorien religion - helt analog til kritikken af kategorien samfund (og også her er den term der vurderes som misvisende, også uundværlig). I grunden er religioner træningsprogrammer - træning i de regler der må gælde for ethvert samfund i dets egenskab af nomotop, eller i de særlige regler som asketer og udbrydere opstiller for sig selv eller lader andre, lærere og guruer, opstille for sig. Tidligere religioner bør forstås som 'etnoplastiske re-

101 Zorn und Zeit, 338f.

102 Engelsk oversættelse: God's Zeal. The Battle of the three monotheisms (2009). Selvkarakteristikken 'religionsteoretisk' i en follow-up-tekst: Im Schatten des Sinai. Fussnote über Ursprünge und Wandlungen totaler Mitgliedschaft $(2013,8)$; engelsk: In the Shadow of Mount Sinai (2016).

103 En samlet diskussion fra fag-teologisk hold: Grillmeyer, Müller-Zähringer \& Rahner 2015.

104 Eksempler: Weltfremheit, 156; Sloterdijk \& Heinrichs, Die Sonne und der Tod, 2006, 215. - Hvis religionsfilosofi er nogenlunde præcist defineret med formlen "the philosophical examination of the central themes and concepts involved in religious traditions" (if. Stanford Encyclopedia of Philosophy, jf. engelsk Wikipedia "Philosophy of Religion"), er afstanden til Sloterdijks analyser ikke stor.

105 Det som Clifford Geertz (1973,111f.) kaldte common sense-perspektivet. 
gelsystemer', ${ }^{106}$ og de store religioner der kommer ud af aksetiden, kan bedst forstås som 'transetniske, mentale øvelsessystemer' ${ }^{107}$ Det kan lyde radikalt; men det er logisk nok i et forfatterskab der konstant drøfter temaer som konventionelt kan benævnes religion, på lige fod og i sammenhæng med alt muligt andet der normalt betragtes som noget andet. I Sloterdijks historiske rekonstruktioner har religion været en måde at organisere sig, tænke og forsøge at forstå som var på niveau med de samfund og de muligheder der nu engang var til stede. Derfor foreslår han i øvrigt $i$ et forslag til en nyordning af vidensfelter i et imaginært fremtidsuniversitet - at religionsvidenskab ikke bør betragtes som en selvstændig disciplin, men som en kombination af selvstændige discipliner: retorik, ritualistik og 'administrativik' (!), med tilvalg fra akrobatik og meditation. ${ }^{108}$

Man finder derfor en flertydig holdning til religion i forfatterskabet. Sloterdijk deler en normal tese om at religionernes tid som værdi- og praksisfællesskaber for store befolkningsgrupper er udspillet. I den forstand vil det være en misforståelse at tale om 'religionens genkomst'. Nutiden må finde nye og selvstændige forståelsesrammer og normer. For så vidt forudsætter Sloterdijk den 'religionskritik' der forbindes med oplysningen - ikke fordi den 'havde ret', men fordi den fik ret; ræsonnementet er socio-historisk, mere end principielt filosofisk. Men dermed er også givet at religionskritik i traditionel oplysningsstil selv er blevet irrelevant, i betydningen: Der er ikke flere erkendelsesgevinster at opnå ad denne vej.

En nutidig tilgang må være mindre reduktionistisk og kategorisk. Det vil være historieforfalskning at rekonstruere den religiøse del af kulturhistorien som en illusionernes, undertrykkelsernes eller bedragenes historie. Historiske religiøse fænomener lægger tværtimod op til interesse og agtelse - for de var nødvendige forløbere i de forvandlingsforløb som, på godt og ondt, har ført menneskeheden frem til der hvor den er i dag. Imod Marx' påstand om at al kritik begynder med religionskritikken, anfører Sloterdijk at det er alt for sent ansat: Al kritik begynder med gravitations-kritik. ${ }^{109}$ Religionen hører til ikke på det beståendes side, det der skal kritiseres, ${ }^{110}$ men på kritikkens side. Dette er indlysende når det kommer til de aksiale religioner der er stort anlagte protester imod den sociale verden ('forlad din far og din mor og følg mig') og den materielle verden ('stig ud af genfødslernes tvang', 'undgå døden'); men allerede de traditionelle religioner er surrealistiske protester imod den foreliggende virkelighed.

Afviklingen af religioner som monopol-kulturer er sket ved at mange traditionelt religiøse problemstillinger er blevet 'nybeskrevet' ved hjælp af videnskabeligtrationelle kategorier, som bedre end de traditionelt religiøse kategorier gør dem for-

106 Im selben Boot, 13.

107 Du musst dein Leben ändern, 711.

108 Du musst dein Leben ändern, 249. Jf. Gottes Eifer, 34: religiøse temaer er for vigtige til at overlade til religionsvidenskaben, men må varetages af en almen kulturvidenskab.

109 Was geschah im 20. Jahrhundert?, 113.

110 'Det bestående' skal her ikke mindst forstås som det de fleste betragter som den faktiske verden, ikke kun den sociale (familie, arbejde, stat), men også den 'naturlige' verden (tyngdekraft, lidelse og død). 
ståelige og håndterbare. ${ }^{111}$ Med udgangspunkt $\mathrm{i}$ at religion drejer sig om 'transcendens', dvs. som noget ellers uforklarligt der ligger uden for menneskenes magt og råderum, og som har hørt til religionernes domæne (i dansk religionsfænomenologisk tradition gerne omtalt som 'den anden verden'), kan der nævnes fire måder hvorpå det transcendente $\mathrm{i}$ det moderne er blevet 'nybeskrevet':112 Det ultralangsomme forstås ikke længere som skabelse, forsyn, prædestination, men som biologisk og sociokulturel evolution; voldsomt emotionelle reaktioner som vrede og skam (og i grunden alt det der beskrives i Rudolf Ottos Das Heilige fra 1917) forstås ikke længere som energier sendt udefra, men som bio-psykiske stress-reaktioner; manglende respons fra verden på klager og spørgsmål forstås ikke længere som Guds eller himlens tavshed, men som udtryk for andres konstitutive anderledeshed (som det derfor er klogt at respektere); og menneskelige fællesskaber (folkeslag, menigheder) og deres karakter af immunsystemer ses ikke længere som funderet af guddommelige magter (skabelse, udvælgelse, kaldelse), men som kollektive dannelser med to formål: at give mening til lidelse, død, uorden og tilfældigheder og til at kanalisere og rammesætte den ubetvingelige trang til overdrivelse (hvilket i nutiden typisk vil sige 'kunst').

Et påtrængende problem - som udfoldes i resten af Gottes Eifer - er at immunsystemer (her: religioner og retninger inden for religioner ${ }^{113}$ ) også konkurrerer. De har både en positiv og en negativ side: Den positive side er at integrere individer i sociale systemer og give sociale, materielle og intellektuelle rammer der både er beroligende og produktive. Den negative side er at de muliggør 'zelotisk'114 adfærd, dvs. gør det meningsfuldt, og nærliggende, for individer at kaste sig ud i kampe, under tiden til døden, for netop deres immunsystems sandhed og krav på monopol. Opfattelsen af religioner som kulturelle immunsystemer er udtryk for en opdateret version af oplysningens religionskritik. Det nye her er ikke mindst at trosmanifestationer ikke betragtes som udtryk for menneskelige fejl, 'men som overflodsfænomener som kronisk udsætter mennesker for en overdreven mængde af opløftende og forenende energier'. ${ }^{115}$ Den hviler på en 'overreaktions-antropologi', i

111 Her er Sloterdijk på linje med James Georges Frazer, som kunne afvige fra sin sædvanlige naturalistiske triumfalisme (naturalismen er sand) og indskrænke sig til at naturalismen er den hidtil mest overbevisende tænkning (Frazer 1922, 932).

112 Gottes Eifer, 16-29. - Sloterdijk nævner desuden tre måder hvorpå transcendens indtil nu har modsat sig naturalistiske forklaringer (for ikke at sige trivialiseringer): (1) forestillingen om en overmenneskelig intelligens (den inspirerer menneskelig tænkning til at prøve at overgå sit hidtidige niveau, dvs. at 'turde lære'); (2) forestillingen om et sted for de døde; (3) modtagelse af åbenbaringer og inspiration; i nutiden betyder bevidstheden om at meddelelser udefra under alle omstændigheder sker på modtagerens præmisser, at en 'feudal' underkastelse under en guddommelig magts meddelelser må tænkes som et mere ligeligt forhold - altså med mindre modtagelse af tro og mere vilje til at tro (ibid., 29-35).

113 Sloterdijk vil formentlig medgive at dette gælder aksiale og postaksiale religioner langt mere end de tidlige højkulturers arkaiske religioner, jf. hans anerkendelse af Jan Assmanns vurdering af egyptisk religion (Gottes Eifer, 206-209).

114 'Zelotisk': 'militant nidkærhed', omtrent synonymt med arabisk jihad - efter den jødiske gruppe zeloterne, der af religiøse grunde aktivt bekæmpede den romerske besættelse i 1 årh. e. Kr.

115 Gottes Eifer, 28. 
overensstemmelse med hele Sloterdijks princip om generelt at se det menneskelige ikke som udtryk for mangel, underskud og fejltagelser, men som det uudryddeligt overdrevne og surrealistiske.

Gotters Eifer skitserer hvordan der fra og med aksetiden udvikledes tre 'monoteistiske' religioner - jødedom, kristendom og islam - som dannede tætte, sammenhængende fællesskaber baseret på en overbevisning om at være talerør for det transcendente og derfor om at have ret, inklusive ret til at bekæmpe og indlemme medlemmer af alternative fællesskaber. Men overbevisningen om at have ret, 'supremacisme', 116 inklusive ret til at omforme verden, om nødvendigt med vold, er ikke i sin dybdestruktur specifikt religiøs, for den videreførtes i de militante oplysningsstrømninger, fra den franske revolutions jakobinisme og til leninisme og maoisme. Kaldet til forsage verden er også kaldet til at forsage det i en selv der (endnu) klæber til verden. 'Jeg'et' må forsvinde for at give plads for det ene og sande (Gud ${ }^{117}$, hhv. menneskehedens sag), og jeg'ets forsvinden fører let til bestræbelser på at lade alt det $\mathrm{i}$ verden forsvinde som forhindrer realiseringen af det ene og sande. ${ }^{118}$

Desuden er den vestlige religionshistorie ikke kun historien om forsøgene på zelotisk-voldelige ekspansionsforsøg, men også historien om hvordan disse forsøg slog fejl og tvang religionerne til at tage ved lære og acceptere at det at være i besiddelse af den yderste sandhed ikke behøver at føre til at den også tvinges ned over dem som ikke vil dele den - dvs. at indrette sig på at være en forening, at være en del af et samfund og ikke identisk med samfundet som helhed. Den ældste, jødedommen, var også den der lærte først - af nederlagene i oldtidens oprør imod den romerske overmagt. Kristendommen lærte sin lektie efter religionskrigene i 1600tallet. Islam er, if. Sloterdijks diagnose, endnu i den lærende fase; pt. fører den klart på point $\mathrm{i}$ henseende til at være den bedste til at gøre sig upopulær blandt ikkemedlemmer. ${ }^{119}$

Nutidige nyforståelser af religionernes anliggender betyder ikke at religionerne dør, men heller ikke at de igen kan komme til at dominere. I den forstand er det misvisende at tale om 'religionernes genkomst'; hvis dette menes i seriøs forstand, altså som zelotisk stræben efter universelt herredømme, vil det være et projekt som er dømt til at mislykkes. Og omvendt er det overflødigt, klodset ('tolpatschig'), trivielt og misvisende at drive religionskritik i neo-ateistisk udgave. ${ }^{120}$ Overflødigt fordi den post-religiøse epoke, kapitalismen (jf. ovenfor) er solidt selvbærende. Trivielt fordi ateismen kun kan repetere trivialiteter. Klodset fordi fornuften ellers har lært at også dén har grænser for hvad den kan og bør udtale sig om. ${ }^{121} \mathrm{Og}$ misvisende:

116 Ikke at forveksle med den russiske æstetisk-ideologiske avantgarde-bevægelse 'suprematisme' fra begyndelsen af 1900-tallet; jf. engelsk Wikipedia: "Supremacism".

117 Man kan illustrere Sloterdijks ræsonnement med Grundtvig, som lejlighedsvis kunne reaktivere en pietistisk tradition: “Det er den snævre port for sjælen, / for det i os, som siger 'jeg', / hvis ære med den dybe knælen/ indlysende forliges ej; / skønt intet værd er, hvad vi mister, / os egenkærlighed dog frister / til på 'os selv' at holde fast' (Gud Helligånd, vor igenføder, 1852-53).

118 Gottes Eifer, 214.

119 Gottes Eifer, 178.

120 Du musst dein Leben ändern, 9.

121 Kritik der zynischen Vernunft, 73. 
En sådan kritik tager ikke højde for at også religioner er selvregulerende organismer der er i stand til at blive klogere, og den vil ikke indrømme at uden religionernes træningsprogrammer for tænkning, viden og kunst ville menneskeheden overhovedet ikke være i sin aktuelle civilisatoriske tilstand. Endeligt er det ikke umuligt at de store religioner også kan afgive inspiration til hvordan store trans-etniske grupper kan organisere et internt liv på en nogenlunde konflikthæmmende måde. ${ }^{122}$

Gottes Eifer rummer endelig en politisk morale: Stillet over for nutidige udbrud af religiøs zelotisme, med militant islam som den reelt eneste alvorlige udfordring i nutiden, vil det være fejlagtigt at opstille konfliktzonen som om den stod imellem religion og modernitet. Moderniteten har haft sine egen erfaringer med ateistisk supremacisme og zelotisme, som i henseende til skadevirkninger har overgået de religiøse udgaver. Konfliktzonen bør i stedet stå imellem zelotisme og moderation. ${ }^{123}$ Det kalder på en alliance imellem en moderat modernitet der har lært at dæmpe sine tidligere forestillinger om at være kaldet til at remodellere verden, og en moderat religiøsitet som har lært at fungere på en ikke-religiøs omverdens præmisser, inkl. tilstedeværelsen af konkurrerende religioner. ${ }^{124}$

\section{Selvagtelse og træning}

I bogen Zorn und Zeit (2008) argumenterer Sloterdijk for betydningen og legitimiteten af emotionelle fænomener som selvagtelse, stolthed, sans for ret og uret, som han forener under det klassisk græske begreb thymós. Disse fænomener er forbundne med vrede - et urfænomen if. den europæiske kulturhistorie. Hvis Homers Iliaden er det første litterære værk i vestlig kulturhistorie, er 'vrede' (mênis) det første ord: "Vreden, gudinde, besyng ....". Her forlænges den kritik af den psykoanalytiske psykologi som var et vigtigt tema i Sphären I, for thymos bør anses for et grundfænomen der ikke kan reduceres til noget andet - såsom begær efter noget andet og evt. mistet. I navnlig en kapitalistisk markedsøkonomi er det ganske vist let at finde en dyb visdom i påstanden om menneskets grundlæggende egoistiske begærlighed; herfra er det let at oversætte og forklare alt der fremtræder som noget andet, som snedigt dække over et dybereliggende begær ('det siger han kun fordi han vil have ... penge, sex, magt, status; jeg, kyniker, er i det mindste ærlig om min kynisme'). Men at mennesker også er 'thymotiske' væsener, viser sig i deres villighed til at afstå fra begærsopfyldelse og ofre deres besiddelse og, i ekstreme tilfælde, deres liv (og, formentlig, jf. overfor, i at betale skat). Vrede fremkaldes af krænkelse, dvs. af brud på hvad der antages for ret og rimeligt, og forandringer i menneskers liv er

122 Ausgewählte Übertreibungen, 381.

123 Gottes Eifer, 105-218.

124 Gottes Eifer, $217 f$. 
ofte fremprovokeret af thymotiske reaktioner. Vrede kan altså absolut være et legitimt fænomen. ${ }^{125}$

Men ukontrolleret thymos er potentielt destruktiv og sammenhængsopløsende; og allerede i den græske oldtid undergår synet på vreden en transformation, over polis-borgerens evne til at moderere sin vrede til stoikerens totale betvingelse af trangen til at give udtryk for sine emotioner. Civilisationens historie er derfor også en fortælling om kollektivt vredes-management i stor stil; og dermed har en historisk rekonstruktion af thymos-forståelsen en uundværlig religionshistorisk komponent. Det tidligste anløb til en religion bygget på opstemmet raseri kan findes i Det Gamle Testamentes salmers bøn om hævn og gengældelse over fjender i almindelighed og babyloniere i særdeleshed (S1 139: "Lykkelig den som griber dine spædbørn og knuser dem mod klippen"). ${ }^{126}$ Faktisk kan de store religioner ses som institutioner, hvor retfærdig harme hverken får direkte afløb eller annulleres, men udskydes til en eskatologisk udløsning - i den vestlige religionshistorie i form af en dommedag, dies ira ('vredens dag'). If. denne forestilling fungerer det hinsides altså som en slags bank hvor der indskydes værdier - krænkelses- og vredes-enheder - til udbetaling på et senere tidspunkt. Religionshistorie er ikke mindst thymoshistorie..$^{127}$

Inspirationen her kommer selvfølgelig fra Nietzsches forestilling om ressentiment, nid og nag, som et udslag af en undertvingelse af uvilkårlige emotioner såsom, ikke mindst, en trang til at hævne begået uret. Men ud over at Nietzsches anklage imod netop kristendommen som særlig ressentiment-fremmende og emotions-hæmmende er fejlanbragt if. Sloterdijk, ${ }^{128}$ er thymos-administration også civilisatorisk nødvendigt. Forestillingen om historien som en stadig akkumulation af krænkelser bevares i post-religiøse ideologier, kulminerende med kommunismen hvor revolution begrundes i en dennesidig og nutidig, retfærdig tilbagebetaling. ${ }^{129} \mathrm{Og}$ efter murens fald slår nye vredesbål op overalt, fra lokale bilafbrændinger til den globale, militante islamismes raseri imod nutiden. Ud over at skulle kunne modstå og bekæmpe også denne udfordring, uden at henfalde til et symmetrisk mod-raseri (fx i form af en 'war on terror'), er udfordringen at give rum til en moderat thymos, ikke mindst politisk. Men det indebærer at mennesker i mindre grad ser sig selv som 'erotiske' væsener, dvs. som mere end begærsdrevne og krævende modtagere af

125 Bogen foregreb altså aktuelle fænomener som 'Wutbürger' ('raseri-borger'; årets ord i Tyskland 2010) og valget af Donald Trump til præsident i USA i 2016. Jf. Sloterdijks kommentar til borgerprotester i Tyskland imod politiske beslutninger der opleves som udemokratiske: “Letzte Ausfahrt Empörung" (2015).

126 Zorn und Zeit, 129-133.

127 En detalje: den middelalder-katolske lære om Purgatoriet er et udslag af en rosværdig lavthymotisk bank-tænkning: Med gode gerninger kan man indbetale afdrag på sin skyld på forhånd og afdrage på skylden efterlods; Luther derimod ville vende tilbage til en høj-thymotisk lære om direkte afregning (Zorn und Zeit, 162-169).

128 Zorn und Zeit, 49: Allerede i 1800-tallet havde kristendommen afgivet sine thymotiske energier til nationalistiske og internationalistiske bevægelser.

129 Sloterdijk er mere diskret når det kommer til postkommunistiske ideologier og nøjes med at antyde eksistensen af fx feministiske eller postkoloniale vredes-banker (p. 354). 
materielle goder og oplevelser, og mere som myndige borgere der kan undvære og som kan afslå goder for at kunne bevare deres selvagtelse.

Med fremhævelsen af thymos som en elementær drift - der kan doseres i mange grader, fra Achilleus' aristokratisk-infantile vrede til de vestlige samfunds postdemokratisk-velfærdskrævende masser uden stolthed og selvrespekt - kombinerer Sloterdijk antropologi med religionsteori. Og samtidig er thymos formentlig tænkt som et grænsebegreb til askese, dvs. træning, øvelse, som er temaet i den store bog Du musst dein Leben ändern. Kulturer, herunder religioner, er mere end thymotisk gruppe- og individ-administration og imaginær vredes-ophobning. De er også og først og fremmest kollektive træningsprogrammer. Og selv om de kan fremstå og forstås primært som opretholdelses- og bevarelsestræning, ikke forandrings- og forbedringstræning, er resultatet ikke desto mindre stadig forandring, effektivisering og eksplicitering. Tilsammen giver fænomenerne thymos og askese et bud på den kulturelle evolutions motor. At den menneskelige art er involveret i en kulturel evolution er en trivialitet; mindre trivielt er det på hvilke måder og i hvilke henseender. Sloterdijks mange historiske rekonstruktioner er i grunden én og samme historie, genfortalt i mange tonearter eller koder. Men hvis man spørger efter den minimale betingelse for hvordan den menneskelige historie overhovedet kunne ske, og det $\mathrm{i}$ et tempo hvis tekniske acceleration ikke synes at tage af, vil svaret formentlig være netop de thymotiske og asketiske elementar-egenskaber. Mennesket er altså det selvagtende og trænende dyr. Både thymos og askese har destruktive potentialer og kan udløse katastrofer, og det er med god grund at socio-kulturelle systemer og epoker, herunder navnlig religioner, har gjort hvad de kunne for at tøjle og kanalisere de menneskelige energier. Men imellem konstateringen af at menneskehedens historie endnu ikke er gået i stå og håbet om at kunne udskyde universelle katastrofer på ubestemt tid, imellem traditionel miserabilisme og brutal liberalisme, kan man med Sloterdijk nøgternt konstatere at 'vi' lever i ikke i en miserabel jernalder, men trods alt, som i den græske mytologske digter Hesiods fortælling om verdensaldrene, i en slags sølvalder. ${ }^{130}$ ' $\mathrm{Vi}^{\prime}$ - altså dem der er inde i nutidens drivhus, og: så længe det varer.

\section{LITTERATUR}

Baunvig, Katrine Frøkjær, og Hans J. Lundager Jensen

2016 "Storpolitik i det 21. årh. er kun mulig som udvidet autohjælp", Kristeligt Dagblad, 7. jan.

Couture, Jean-Pierre

2015 Sloterdijk, Polity.

Descola, Philippe

2005 Par-delà nature et culture, Gallimard.

Eliade, Mircea

1961 “A New Humanism”, in: Idem, Images and Symbols, Sheed Andrews \& McMeel, 1-11.

130 Du musst dein Leben ändern, 516, 669-672 - med henvisning til den amerikanske pragmatiske filosof Richard Rorty der med bogen Achieving Our Country (1998) argumenterede for det legitime i forestillinger om verdensforbedring og fædrelandsstolthed. 
Frazer, James George

1922 The Golden Bough. A Study in Magic and Religion, Abridged Edition, Macmillan.

Geertz, Clifford

1973 “Religion as a Cultural System," in: Idem, The Interpretation of Cultures, Basic Books, 87-125.

Grillmeyer, Siegfried, Erik Müller-Zähringer \& Johanna Rahner , eds.

2015 Peterchens Mondfahrt-Peter Sloterdijk, die Religion und die Theologie, Echter.

Klostergaard Petersen, Anders, og Hans J. Lundager Jensen

2013 “Tema: Religionshistorie og kulturel evolution", Religionsvidenskabeligt Tidsskrift 60, 3-4.

Knott, Kim

2008 "Spatial Theory and the Study of Religion", Compass 2 (6), 1102-1116.

Latour, Bruno

2005 Reassembling the Social. An Introduction to Actor-Network Theory, Oxford University Press.

2009 "Spheres and Networks: Two Ways to Reinterpret Globalization", Harvard Design Magazine, 30, 138-144.

Lundager Jensen, Hans J.

2013 "Udstigere og immunsystemer, asketer og akrobater", Religionsvidenskabeligt Tidsskrift 60, 75-97.

2016a “Ontologier i Det Gamle Testamente: analogisme og animisme (Gen 1 og 2-3)”, Collegium Biblicum Årsskrift, 1-19.

2016b “Land, by, netværk: Tre religionstyper i Bibelen”, Kritisk Forum for Praktisk Teologi 143, 3-19.

Morin, Marie-Eve

2009 "Cohabitating in the globalised world: Peter Sloterdijk's global foams and Bruno Latour's cosmopolitics", Society and Space 27, 58-72.

Røsing, Lilian Munk

2016 “Tysk filosof giver løsningen på verdens problemer", Politiken 2016-06-20.

Schinkel, Willem \& Liesbeth Noordegraaf-Eelens

2011 In Medias Res. Peter Sloterdijk's Spherological Poetics of Being, Amsterdam University Press.

Schreiber, Michael

2013 "Raumdialog", in: Michael Hoffmann, Michael Schreiber \& Björn Stüwe, Bad Inspirationen 4. Das intregrale Bad: Vom Lebens- zum Erlebnisraum, Bruchsal: SHK Einkaufs- und Vertriebs AG, 404413.

Sloterdijk, Peter

1983 Kritik der zynischen Vernunft, Suhrkamp.

1989 Kritik af den kyniske fornuft, Hans Reitzel.

1993 Weltfremdheit, Suhrkamp.

1998 Sphären I: Blasen, Suhrkamp.

1999 Regeln für den Menschenpark. Ein Antwortschreiben zu Heideggers Brief über den Humanismus, Suhrkamp.

1999 Sphären II: Globen, Suhrkamp.

2000 Die Verachtung der Massen. Versuch über Kulturkämpfe in der modernen Gesellschaft, Suhrkamp.

2001 Nicht gerettet. Versuche nach Heidegger, Suhrkamp.

2001 Über die verbesserung der guten Nachricht. Nietzsches fünftes "Evangelium", Suhrkamp.

2004 Sphären III: Schäume, Suhrkamp.

2005 Im Weltinnenraum des Kapitals, Suhrkamp.

2007 Gottes Eifer: Vom Kampf der drei Monotheismen, Verlag der Weltreligionen.

2008 Zorn und Zeit. Politisch-psychologischer Versuch, Suhrkamp.

2009 Du musst dein Leben ändern, Suhrkamp.

2009 "Talking to Myself about the Poetics of Space", Harvard Design Magazine 30, 126-137.

2010 Die nehmende Hand und die gebende Seite, Suhrkamp.

2010 "Warum ich doch recht habe", Zeit Online. 2. 12 2010. http://www.zeit.de/2010/49/SloterdijkReichensteuer/komplettansicht.

2011 Stress und Freiheit, Suhrkamp. 
2013 Im Schatten des Sinai, Suhrkamp.

2013 Ausgewählte Übertreibungen. Gespräche und Interviews 1993-2012, Suhrkamp.

2014 Der ästhetische Imperativ, Suhrkamp.

2015 "Letzte Ausfahrt Empörung", www.petersloterdijk.net.1. april 2015.

2016 Das Schelling-Projekt: Ein Bericht, Suhrkamp.

2016 Was geschah im 20. Jahrhundert?: Unterwegs zu einer Kritik der extremistischen Vernunft, Suhrkamp.

Sloterdijk, Peter, og Hans-Jürgen Heinrichs

2006 Die Sonne und der Tod, Suhrkamp.

Sloterdijk, Peter, og Thomas Macho

2014 Gespräche über Gott, Geist und Geld, Herder.

Zimmer, Carl

2016 "Scientists Ponder on Evolutionary Mystery: The Female Orgasm", The New York Times. 1.

August 2016. http://www.nytimes.com

Hans J. Lundager Jensen, professor, dr. theol., Afdeling for Religionsvidenskab og Afdeling for Teologi, Aarhus Universitet hj@cas.au.dk 